\title{
Mass Calibrations
}

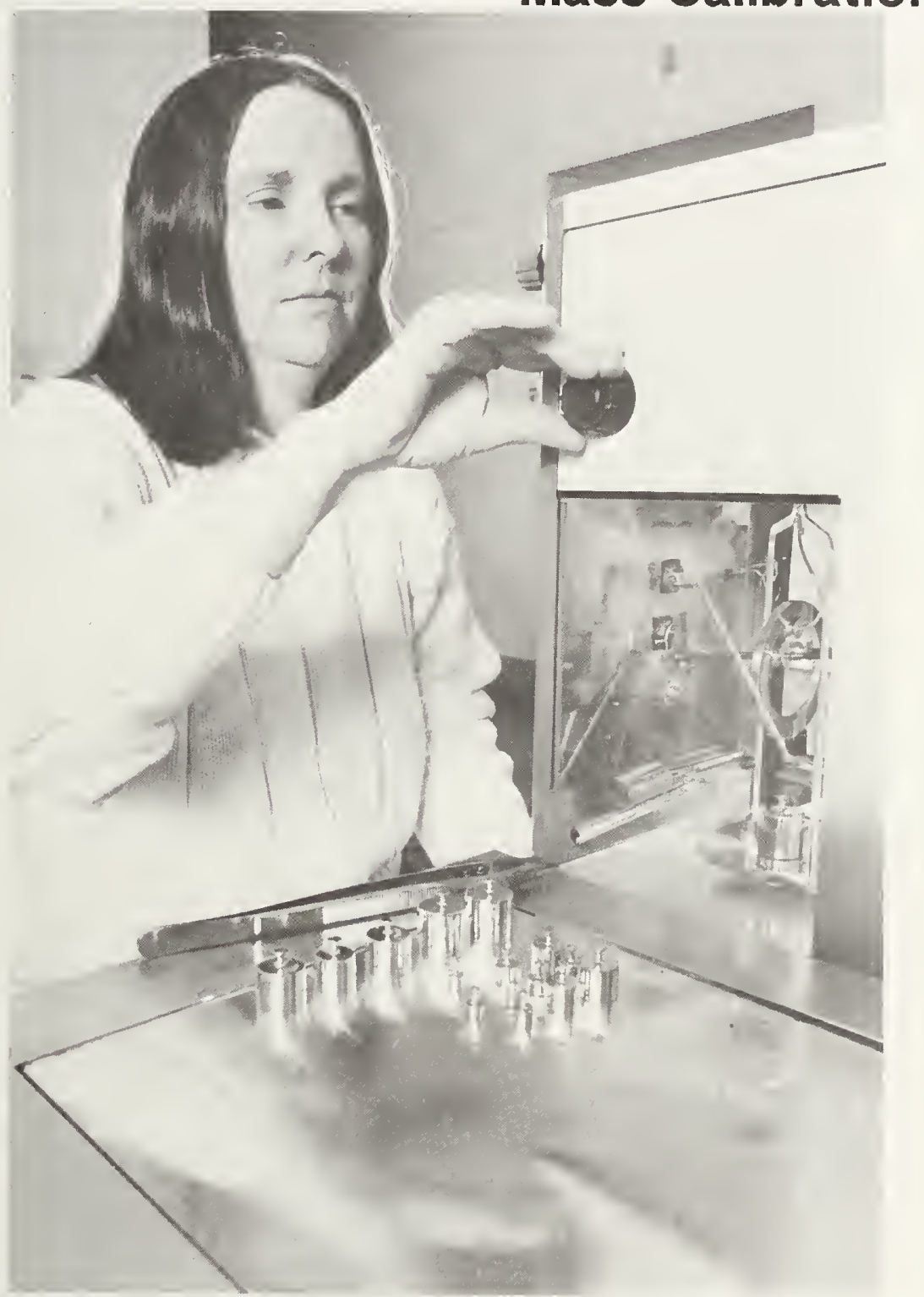

NIST

Special

Publication

250-31

R. S. Davis 


\section{Center for Manufacturing Engineering}

The Center for Manufacturing Engineering provides competence and develops technical data, findings, and standards in manufacturing engineering, mechanical metrology, automation, robotics, control technology, and precision mechanical engineering to support the discrete parts manufacturing industries; the Center also controls/maintains the Automated Manufacturing Research Facility (AMRF) and consists of five Divisions.

\section{Precision Engineering Division}

Develops/maintains competence in metrology for length, mass, and angle, optics, machine-tool metrology, precision machining, and nanotechnology; incorporates metrology into precision manufacturing, including lithography and metal working processes as well as the standards necessary for integration of equipment up to the manufacturing cell level.

\section{Robot Systems Division}

Develops/maintains competence in robotics, real-time sensory-interactive control technology, robot languages/ standards, and interface standards for computer-integrated manufacturing systems; conducts research into new techniques of sensing and control, sensory data processing and communications, world models, robot programming languages, interactive graphics for programming, and intelligent real-time control for industrial, military, space and construction applications; develops experimental robot applications; performs technical activities relating to standards for robots and computer-integrated manufacturing systems; performs research in robot safety, robot assembly of parts, tools, and fixtures, and applications of intelligent control to military and industrial systems.

\section{Factory Automation Systems Division}

Develops/maintains competence in computer science/software engineering, industrial engineering, control systems engineering, and mechanical engineering including research into new techniques of intelligent machine processes and machine-readable product data that merge technologies of artificial intelligence, information systems, metrology, and industrial processes; performs technical analyses for feasibility of interface standards and product data specifications for manufacturing systems; interfaces manufacturing data preparation systems such as computer-aided design, process planning, and off-line equipment programming with the manufacturing control systems; performs research/development on interfaces necessary to manage factory communication network protocols and database management systems in a manufacturing environment; develops techniques for the computer-assisted and automated generation of control code required for executing processes involved in discrete-parts manufacturing industries.

\section{Automated Production Technology Division}

Develops/maintains competence in integration of machine tools and robots up to manufacturing cell level; develops interfaces/networks necessary to combine robots and machines into workstations and workstations into manufacturing cells; develops/maintains computer-assisted techniques for generation of computer code for integration of machine tools and robots; maintains competence in engineering measurements and sensors, both static and dynamic, of force and force related quantities, and other parameters required by discrete-parts industry; conducts research on nature of the measurement process and transducers and the development, characterization, and calibration of transducers used in discrete-parts manufacturing.

\section{Fabrication Technology Division}

Designs, fabricates, repairs, and modifies precision apparatus, instrumentation, components thereof, and specimens necessary to the experimental research and development work of NIST; develops/maintains competence in CAD/CAM, automated process planning, and shop management systems. 


\section{NIST MEASUREMENT SERVICES: Mass Calibrations}

R. S. Davis

Precision Engineering Division

Center for Manufacturing Engineering

National Engineering Laboratory

National Institute of Standards and Technology

Gaithersburg, MD 20899

January 1989

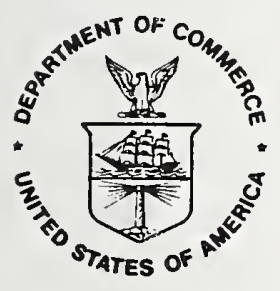

NOTE: As of 23 August 1988, the National Bureau of Standards (NBS) became the National Institute of Standards and Technology (NIST) when President Reagan signed into law the Omnibus Trade and Competitiveness Act.

U.S. DEPARTMENT OF COMMERCE, C. William Verity, Secretary

Ernest Ambler, Acting Undersecretary for Technology

NATIONAL INSTITUTE OF STANDARDS AND TECHNOLOGY, (formerly National Bureau of Standards)

Raymond G. Kammer, Acting Director 


\section{Library of Congress Catalog Card Number: 88-600608}

National Institute of Standards and Technology Special Publication 250-31 Natl. Inst. Stand. Technol., Spec. Publ. 250-31, 72 pages (Jan. 1989) CODEN: NSPUE2 


\title{
PREFACE
}

Calibrations and related measurement services of the National Institute of Standards and Technology provide the means for makers and users of measuring tools to achieve levels of measurement accuracy that are necessary to attain quality, productivity and competitiveness. These requirements include the highest levels of accuracy that are possible on the basis of the most modern advances in science and technology as well as the levels of accuracy that are necessary in the routine production of goods and services. More than 450 different calibrations, measurement assurance services and special tests are available from NIST to support the activities of public and private organizations. These services enable users to link their measurements to the reference standards maintained by NIST and, thereby, to the measurement systems of other countries throughout the world. NIST Special Publication 250, NIST Calibration Services Users Guide, describes the calibrations and related services that are offered, provides essential information for placing orders for these services, and identifies expert persons to be contacted for technical assistance.

NIST Special Publication 250 has recently been expanded by the addition of supplementary publications that provide detailed technical descriptions of specific NIST calibration services and, together with the NIST Calibration Services Users Guide, they constitute a topical series. Each technical supplement on a particular calibration service includes:

\author{
- specifications for the service \\ - design philosophy and theory \\ - description of the NIST measurement system \\ - NIST operational procedures \\ - measurement uncertainty assessment \\ error budget \\ systematic errors \\ random errors
}

- NIST internal quality control procedures

The new publications will present more technical detail than the information that can be included in NIST Reports of Calibration. In general they will also provide more detail than past publications in the scientific and technical literature; such publications, when they exist, tend to focus upon a particular element of the topic and other elements may have been published in different places at different times. The new series will integrate the description of NIST calibration technologies in a form that is more readily accessible and more useful to the technical user.

The present publication, SP 250-31, NIST Measurement Services: Mass Calibration at the National Institute of Standards and Technology, by $R$. S. Davis, is one of the documents in the new series. It describes calibration technology and 
procedures utilized in connection with NIST Service Identification Numbers from 22010C to 22180M listed in the NBS Calibration Services Users Guide 1986-

88/Revised (pages 28-31). Inquiries concerning the contents of these documents may be directed to the author(s) or to one of the technical contact persons identified in the Users Guide.

Suggestions for improving the effectiveness and usefulness of the new series would be very much appreciated at NIST. Likewise, suggestions concerning the need for new calibration services, special tests and measurement assurance programs are always welcome.

Joe D. Simmons, Acting Chief Office of Physical Measurement Services 
Contents

Page

1. Description of Service. . . . . . . . . . . . . . . . . . . 1

2. The International System of Units . . . . . . . . . . . . . . . . . . 2

3. Mass Standards in Practice. . . . . . . . . . . . . . . . . . 3

3.1 Kilograms. . . . . . . . . . . . . . . . . . . . 3

3.2 Other Denominations. . . . . . . . . . . . . . . 6

4. Density Determination of Single-Piece Kilograms

Using Submersible Balance . . . . . . . . . . . . . . . . . . 7

4.1 Apparatus. . . . . . . . . . . . . . . . . . . . . . . 8

4.2 Principles of Use. . . . . . . . . . . . . . . . . 10

5. Cleaning of Weights . . . . . . . . . . . . . . . . . . . . 11

5.1 Categories of Weights. . . . . . . . . . . . . . . . 11

5.2 Cleaning Procedures. . . . . . . . . . . . . . . . 12

5.2.1 One-Piece Weights . . . . . . . . . . . . . . . . 12

5.2.2 Screw-Knob Weights. . . . . . . . . . . . . . 12

5.2.3 Sheet-Metal Weights . . . . . . . . . . . . 13

5.3 Temperature Equilibrium. . . . . . . . . . . . . . . 13

5.4 Storage. . . . . . . . . . . . . . . . . . . . 13

5.5 Brushes. . . . . . . . . . . . . . . . . . . 14

6. Method of Calibrating Dead Weights. . . . . . . . . . . . . . . . 14

6.1 Measurement Algorithm. . . . . . . . . . . . . . . 14

6.2 Uncertainty of Value Assigned to Piston Weights. . . . . . . . . 15

7. Method of Calibrating Standard Weights. . . . . . . . . . . . . 15 
7.1 Measurement Algorithm. . . . . . . . . . . . . . . . 15

7.2 Uncertainty of Value of Standard Weights . . . . . . . . . . . . 16

8. Quality Control. . . . . . . . . . . . . . . . . . . 16

8.1 F-Test. . . . . . . . . . . . . . . . . . . 19

8.2 t-Test. . . . . . . . . . . . . . . . . . . . 19

8.3 Between-Times Components . . . . . . . . . . . . . . . . 23

9. Future Plans. . . . . . . . . . . . . . . . . . . . . 23

10. References. . . . . . . . . . . . . . . . . . . . . . 25 Appendices
A. Least Squares Analysis. . . . . . . . . . . . . . . . . . . A1
B. Sample Calibration Report . . . . . . . . . . . . . . . . . B1
C. Sample Surveillance Test Report . . . . . . . . . . . . . . . C1
D. Sample Dead-Weight Calibration Report . . . . . . . . . . . . . D1 


\section{Description of Service}

The National Bureau of Standards maintains the national standard for mass in the form of the prototype kilogram K2O and its companion $\mathrm{K} 4$ and provides services to support the segments of the national measurement system which rely directly or indirectly on mass measurements. These services are offered only to those customers whose requirements cannot be met by state laboratories. In order to provide prompt and useful service, the acceptance of the items for calibration or test is based on discussions with each user to determine details necessary to meet measurement and delivery requirements, and on inspection of the item at the Bureau to determine its suitability for the usage intended.

Services are available to enable a user to establish a measurement assurance program for certain measurement processes. This may involve developing procedures for establishing and maintaining a state of statistical control for the measurements, the determination of the offset of the process from the national system, and assisting in the determination of the uncertainty of measurements made by the user's process.

Arrangements for calibration (or test) must be completed before shipping apparatus to the Bureau. While all services are on an actual-cost basis, subject to a $\$ 25$ minimum charge, a mutual agreement on the work to be performed generally results in substantial savings for the user. Detailed packing and shipping instructions are available on request. Items not accepted for calibration or test will be returned, the cost of inspection or the minimum charge will be applicable.

The results of a calibration or test will be reported in a National Bureau of Standards Report of Calibration Test or of Special Test (which in many cases is prepared by a computer program), a continuation report, or a letter report. In each of these, the values reported are accompanied by an appropriate estimate of uncertainty (allowance for random and systematic errors) as determined by an analysis of the specific measurement process. A continuation report is used for those items submitted for recalibration on which preliminary tests indicate that no significant changes have occurred since the last calibration. Usually a letter report is used to report a test for compliance with a specification which states limits for the departure of the actual value from nominal.

Charges for these services are listed in the NBS SP250 Appendix. Upon receipt of a request for services, an estimated cost will be given along with a firm date for completion. An effort will be made to discuss the measurement requirement with the customer so as to give proper service at minimum cost and delay.

The Bureau's calibration of reference standards of mass provides extensions of the mass unit embodied in the NBS standard of mass. A normal calibration consists of establishing a mass value and the appropriate uncertainty for that value for each weight which has been designated to be a reference standard. It is desirable, but not necessary, that a weight meet the adjustment tolerances 
established for NBS Classes A, B, M, or S-1 prior to submission[1].1 Normally weights are available from manufacturers, many of whom can furnish directly documentation suitable for meeting quality assurance contracts and requirements.

Individual weights or sets of weights in the range of $30 \mathrm{~kg}$ to $1 \mathrm{mg}$ or 50 ib to $1 \mu \mathrm{lb}$ in decimal subdivisions, which are designated as reference standards, must be of design, material, and surface finish comparable to, but not necessarily limited to, present NBS Classes A, B, M, S, or S-1.2 Design, material, and surface finish of large mass standards (from 50 to $50,000 \mathrm{lb}$ ) must be compatible with the intended usage. For these large mass standards an adjustment with reference to a nominal or desired value can be included as a part of the calibration procedure.

The values of true mass (and an apparent mass correction) included in the report will be determined by using computed volumes based on the manufacturer's statement of density of the material, on the density computed from measured volumes, or in the absence of this information, on estimated density values. The apparent mass corrections are computed for $20{ }^{\circ} \mathrm{C}$ with reference to Normal Brass (density $8.4 \mathrm{~g} / \mathrm{cm}^{3}$ at $0{ }^{\circ} \mathrm{C}$, volume coefficient of expansion $0.000054 /{ }^{\circ} \mathrm{C}$ ) and to stainless steel (density $8.0 \mathrm{~g} / \mathrm{cm}^{3}$ at $20{ }^{\circ} \mathrm{C}$ ) in an ideal air density of $1.2 \mathrm{mg} / \mathrm{cm}^{3}$. Apparent mass corrections to any other basis can be furnished if requested.

For periodic recalibrations of reference mass standards, the user need measure only differences between weights or groups of weights within a set and compare them with computed differences. As long as the agreement is within allowable limits, the values can be considered constant within the precision of the comparison process. Mass standards which are submitted to the Bureau for recalibration frequently are tested in this manner. If these tests indicate that no significant changes have occurred, a continuation report so stating and referring to the previous NBS Report of Calibration will be issued.

\section{The International System of Units}

Virtually all industrialized countries are signatories to a treaty which establishes a consistent set of measurement units. The convention which has been agreed to is called the International System of Units. It is frequently abbreviated as SI (for Systeme International d'Unites, the treaty having been written in French). An international committee, which was established through a provision of the treaty, sees to it that the definitions of units in the SI change to reflect improvements in measurement technology. In the case of the

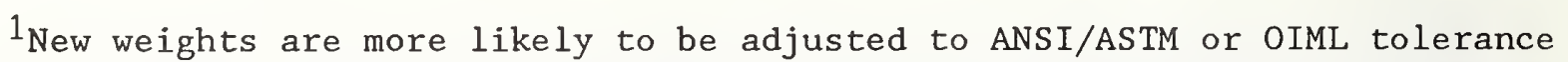
[2,3]. We will accept ASTM Classes 1, 2, and 3 as well as OIML Classes E1, E2, F1, and F2. (See ASTM E617.)

${ }^{2}$ We will also accept ANSI/ASTM Grades $S$ and 0 as well as OIML classes E1, E2, F1, or F2. 
unit of mass, however, there has been no change in the definition for almost 100 years.

The unit of mass in the SI is the kilogram. Its value is defined with reference to an object known as the International Prototype Kilogram (IPK). The definition can be simply stated:

"A kilogram is equal to the mass of the International Prototype of the kilogram."[4]

The IPK is kept and used under the supervision of the International Bureau of Weights and Measures (BIPM) on land provided by the French government in Sèvres, near Paris. [5]

It is then necessary to establish a practical system of mass measurement based on the simple definition.

\section{Mass Standards in Practice}

\subsection{Kilograms}

The first step is the easiest to achieve. Countries, such as the United States, possess at least one replica of the IPK. These replicas are made of the same material as the IPK (an alloy of 90 percent platinum/10 percent iridium; density $21.5 \mathrm{~g} / \mathrm{cm}^{3}$ ), and have the same shape (a cylinder whose height equals its diameter). The replicas are only within 1 milligram of the IPK but differences between the replicas and the IPK can still be measured using the best balances (such balances have the almost incredible precision of 1 microgram in 1 kilogram, or $1 \times 10^{-9}$ ). Thus each replica must be compared either directly or indirectly with the IPK in order to establish its mass. The U.S. bases its mass measurements on the value of replica no. 20 (sometimes referred to as $\mathrm{K} 20$ ), which is kept at the National Bureau of Standards in Gaithersburg, MD. The difference between the mass of the IPK and K20 was determined in 1890 and again in 1948. In $1984 \mathrm{~K} 20$ was compared indirectly with the IPK. A detailed account of these latest measurements and a review of previous measurements involving the replicas can be found in [6]. The mass of $\mathrm{K} 20$ is thus known to be $1 \mathrm{~kg}-0.020 \mathrm{mg}$ with an uncertainty of less than $0.010 \mathrm{mg}$. Notice that, while the mass of the IPK is $1 \mathrm{~kg}$ by definition and thus has no uncertainty, the mass value assigned to $\mathrm{K} 20$ is not exactly equal to its nominal value and does have a finite uncertainty.

The IPK and its replicas, such as $\mathrm{K} 20$, are made of platinum/iridium for a variety of reasons chief among which is resistance to chemical attack. The expense of this alloy has precluded and still precludes the widespread use of platinum/iridium weights. In the first half of this century, brass weights, usually plated with nickel or rhodium, were the best quality weights commercially available. More recently, stainless steel has supplanted plated brass as the material with which the highest quality commercial weights are fabricated. 
Aside from the fact that plated brass or stainless steel are not as resistant to chemical attack as is platinum/iridium, the major difference between kilograms made of $\mathrm{Pt} / \mathrm{Ir}$ and those of brass or steel is their size, more specifically their volume. One kilogram of $\mathrm{Pt} / \mathrm{Ir}$ has a volume of about 46.5 $\mathrm{cm}^{3}$; but a typical stainless steel kilogram has a volume of about $125 \mathrm{~cm}^{3}$ and one of brass has a volume of about $119 \mathrm{~cm}^{3}$. The difference in volume between a Pt/Ir kilogram on the one hand and a brass or steel kilogram on the other is so great that the buoyant effect of the air which surrounds the kilograms cannot be neglected during weighing. If, for instance, one constructed a stainless steel kilogram weight which exactly balanced the IPK when the two were compared on the most precise balance available, the stainless weight would actually have a mass of about $1 \mathrm{~kg}+94 \mathrm{mg}$. The "extra mass" came about because the measurements were done in air. Air is a fluid which, like any fluid, produces a buoyant effect on objects it surrounds. The effect can be as large and dramatic as the Goodyear blimp. However, when it comes to mass standards and weighing in general, the effect is small but extremely nettlesome. In the case of the Pt/Ir and steel kilograms just mentioned, the buoyant force on the steel exceeded that on the Pt/Ir so that almost $0.1 \mathrm{~g}$ extra steel was needed to balance the two weights. Had the weighing been done in the absence of air, i.e. in vacuum, there would have been no problems due to air buoyancy: the mass of stainless steel which would exactly balance the IPK would have been exactly 1 kilogram. The buoyancy effects are illustrated in figure 1 .

Our concept of mass requires that the mass of an object be the same in vacuum or air (or any other fluid) providing that the total amount of material comprising the object has not changed (i.e, the weight does not dissolve, evaporate, react chemically, etc. with the fluid which surrounds it). Thus a correction must be applied to mass measurements made in air between standards of different volumes. Let us return to the imaginary measurement in air which showed that a stainless steel kilogram exactly balanced the IPK. The results of this measurement can be stated in several different ways:

MASS :

The mass of the stainless steel object is about $1 \mathrm{~kg}+94 \mathrm{mg}$.

TRUE MASS :

The true mass of the stainless steel object is about

$1 \mathrm{~kg}+94 \mathrm{mg}$ (true mass = mass)

VACUUM MASS :

The vacuum mass of the stainless steel object is about $1 \mathrm{~kg}+94 \mathrm{mg}$. (vacuum mass = mass).

APPARENT MASS: The apparent mass of the stainless steel kilogram is about $1 \mathrm{~kg}+0.0 \mathrm{mg}$ when measured against $\mathrm{Pt} / \mathrm{Ir}$ standards in air of density $1.2 \mathrm{~g} / \mathrm{cm}^{3}$ at a temperature of $20{ }^{\circ} \mathrm{C}$.

Note that when specifying apparent mass, one must define the specific weighing conditions. Whereas the mass of an object is a fundamental attribute, its apparent mass will depend on its density, the density of the standard to which it was compared, and the density of air at the time the measurements were made. (The temperature at which the measurements were made must be specified also because the density of stainless steel, Pt/Ir, and other materials is a slight function of temperature.) Because apparent mass is defined through a particular convention, it is sometimes referred to as "conventional mass." 


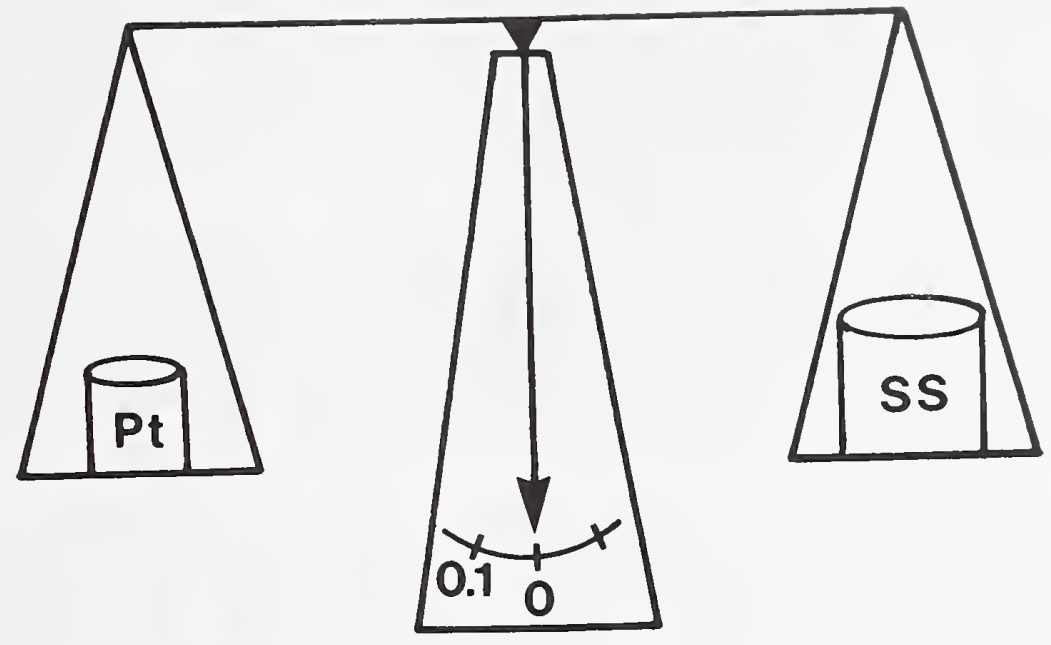

A.

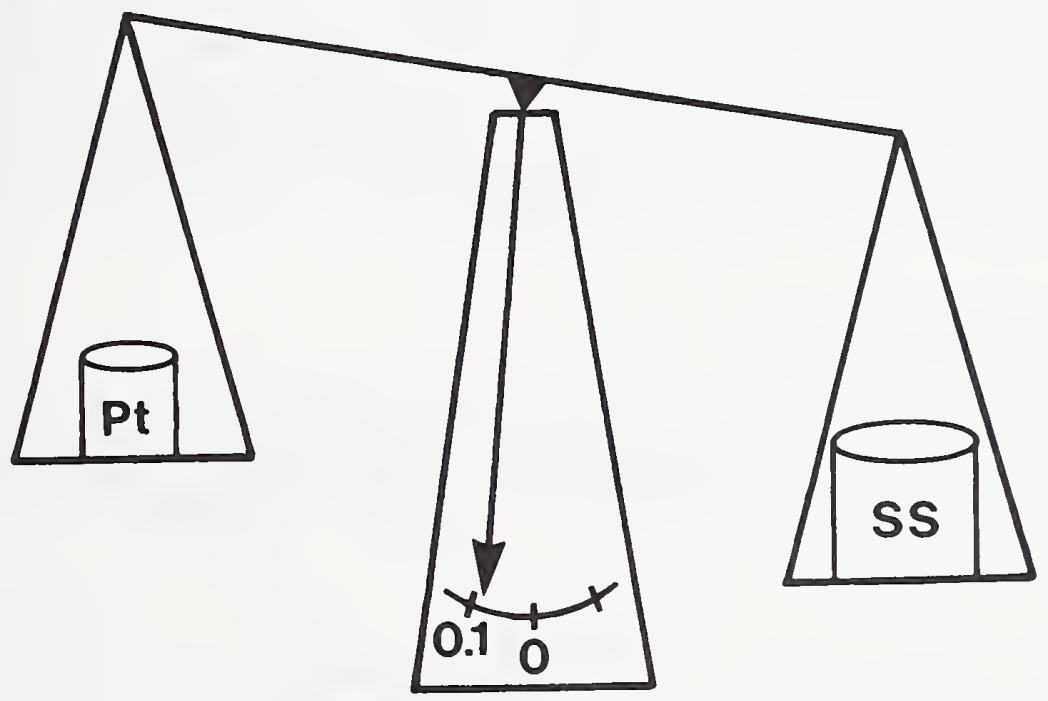

B.

Figure 1. A. A stainless-steel kilogram (density $8000 \mathrm{~kg} / \mathrm{m}^{3}$ ) balances a platinum-iridium kilogram (density $21500 \mathrm{~kg} / \mathrm{m}^{3}$ ) at normal atmospheric conditions. B. Under vacuum conditions one can see that the mass of the stainless-steel kilogram actually exceeds that of the platinum kilogram by about $0.1 \mathrm{~g}$. 
The two conventions in widest use are: density $8.0 \mathrm{~g} / \mathrm{cm}^{3}$ at $20{ }^{\circ} \mathrm{C}$ in air of density $1.2 \mathrm{~g} / \mathrm{cm}^{3}$; and density $8.39094 \mathrm{~g} / \mathrm{cm}^{3}$ at $20{ }^{\circ} \mathrm{C}$ in air of density 1.2 $\mathrm{g} / \mathrm{cm}^{3}[7]$.

Mass in SI units is truly mass (or "vacuum" mass or "true" mass). When the National Bureau of Standards (NBS) calibrates a stainless steel kilogram in terms of its Pt/Ir national standard, a correction of order 0.1 grams must be made to the raw data. This correction is large compared to the precision of the mass comparison. Making the correction requires a great deal of effort. Even doing the best one can, this buoyancy correction can be the major contributor to the uncertainty in the calibration of the stainless steel

kilogram. If the steel kilogram is then used to calibrate other steel or brass kilograms, the buoyancy corrections will be small and relatively easy to apply. The use of stainless steel or other nickel-chrome alloys as "working standards" also means that $\mathrm{K} 20$ can be used very infrequently, thereby minimizing wear and the chance of accident.

The strategy of NBS was to put great effort into the calibration of two standards, N1 and $\mathrm{N} 2$, having a density of $8.35 \mathrm{~g} / \mathrm{cm}^{3}$. These two weights, made of a nickel-chrome alloy, are then used to calibrate other weights of similar density on a more routine basis. At the present time, errors in assigning calibration value of $\mathrm{N} 1$ and $\mathrm{N} 2$ with respect to the IPK are not included in error budgets. This practice is now in the process of being revised.

At the time $\mathrm{N} 1$ and $\mathrm{N} 2$ were fabricated, the majority of high-quality weights were made of plated brass; hence the choice of alloy density. Now virtually all high-quality weights are made of stainless steel. For this reason, NBS is in the midst of changing its working standards from $\mathrm{N} 1$ and $\mathrm{N} 2$ to standards of stainless steel density of $8.0 \mathrm{~g} / \mathrm{cm}^{3}$. This will be a relatively slow process because the long-term stability of the new standards must first be established. In addition, the tie to the SI unit is being carefully established so that a meaningful uncertainty can be assigned.

\subsection{Other Denominations}

So far, we have described how the SI mass unit is transferred from the Pt/Ir prototype in Sevres to a nickel-chrome or stainless steel working standard at NBS. Obviously, it is essential to calibrate weights at other nominal values above and below $1 \mathrm{~kg}$.

The concept of how this is accomplished is simple. Once one has a weight which embodies an SI mass value, it is only necessary to find the ratio of the mass of the known weight to the mass of the unknown weight. Since a ratio is dimensionless, these measurements can, in principle, be accomplished by any laboratory with sufficiently sensitive balances. For instance, if we have a kilogram weight calibrated in SI units and we need to know the mass value of a $500-\mathrm{g}$ weight, the following simple approach might be taken: The known 1-kg weight could be used to calibrate a digital electronic balance of 1 kilogram capacity. The unknown 500-g weight could then be placed on the balance and its mass value read directly. (It would also be wise to check the balance linearity and make the necessary corrections for air buoyancy.) Such 
calibrations were, of course, done before the days of electronic balances. Even today, higher precision can usually be obtained with mechanical balances although with a great loss in convenience. Using an equal-arm balance, for instance, one would need an additional 500-g weight. The mass difference between the sum of both $500-\mathrm{g}$ weights could be found with respect to the calibrated $1-\mathrm{kg}$ weight. This is enough information to assign mass values to the two unknown weights. Similar, though more sophisticated, procedures are used to calibrate weights of all denominations beginning with calibrated kilogram standards.

Calibration of a set of weights consists of assigning values for the unknown weights in terms of the known mass of one or more standards. For high precision work, this involves the use of the balance as a comparator which measures the difference between two objects (or two groups of objects) which must have nominally the same mass because of the small "on-scale" range of the comparator. In deriving units which are subdivisions of the basic unit or multiples thereof, a variety of different weighing sets have been used because of convenience or other practical considerations. A typical set is the 5321 series which bridges the range from 10 to 1 . In most cases, the calibration algorithm provides for a check standard, treated as an additional unknown weight, to be used for monitoring the performance of the measuring process. [8]

Precision weighing is usually done by some form of transposition weighing on a two-pan balance or by substitution methods on a one-pan balance [7]. For simplicity, it will be assumed that a well behaved comparator is available and that measurements of differences in the mass of two objects or groups of objects are corrected for air buoyancy effects and other environmental or procedural factors [7]. It is further assumed that the measurements are uncorrelated in the statistical sense and all are of equal precision. (These latter two assumptions are non-trivial and special care has to be taken to insure their validity so that the random error component of the uncertainty is properly evaluated.)

The schedule of measurements for calibration should include provision for a check standard and also for within-run redundancy. The decision as to which one of a number of possible schedules or designs to use for intercomparison of a set of weights depends on items such as the variance associated with individual weights or combinations thereof. The least squares analysis from which the values for the weights and their variances are calculated is presented in Appendix A.

4. Density Determination of Single-Piece Kilograms Using a Submersible Balance

The buoyancy correction is important in precision weighing. For most cases, an assumed density (supplied by the manufacturer) will suffice. However, in the case of $1 \mathrm{~kg}$ standards, it is desirable to measure the density of individual weights. This measurement is now done routinely at NBS for single-piece kilogram and pound weights sent for calibration. The density measurements we use are a modification developed in our laboratory of the usual hydrostatic weighings. A brief description of the technique which we use follows. [9] 


\subsection{Apparatus}

The balance modified for this work is a Mettler PL1200, 3 the important specifications of which are:

$\begin{array}{ll}\text { weighing range } & 0-1200 \mathrm{~g} \\ \text { reproducibility } & <0.005 \mathrm{~g} \\ \text { linearity } & <0.01 \mathrm{~g}\end{array}$

Significant mechanical and electronic modifications were introduced to the balance and its enclosure. Specifically, the weighing cell of the balance was separated from the supporting electronics and placed beneath the surface of an inert liquid (see fig. 2).

Clearly, the fluid in which an electronic measuring cell is immersed must have many special properties: it must be electrically insulating, it must be chemically inert, it must be optically transparent (in order for the servo optics to function properly), and it should not evaporate quickly. These characteristics may be found, for example, in FC-75, a fluorinated fluid manufactured by the 3M Company. A comparison of some of the properties of FC-75 with those of water is given in table 1. An additionally noteworthy property of FC-75 is its immense appetite for gases. For example, the fluid is able to dissolve about $0.3 \mathrm{~g}$ of air per kilogram of fluid. This ability to dissolve atmospheric gases, greatly inhibits bubble formation on immersed objects--one of the most serious problems in conventional high-precision hydrostatic weighing. Finally, the fluid is 77 percent more dense than water at room temperature thereby increasing the signal to noise in comparison to a normal hydrostatic weighing. The major disadvantages of this fluid as compared to water are its large coefficient of thermal expansion and its cost. However, use of FC-75 instead of water for conventional "hydrostatic" weighing has many advantages.[10] The density of FC-75 is usually not known accurately enough for the liquid to serve as a density standard. Instead, the fluid density is calibrated at the time of use by including a solid object of known mass and volume in the weighing scheme.

3 Certain trace mes and company products are identified in order to adequately specify the experimental procedure. In no case does such Identification imply recommendation or endorsement by the National Bureau of Standards nor does it imply that the products are necessarily the best available for the purpose. 


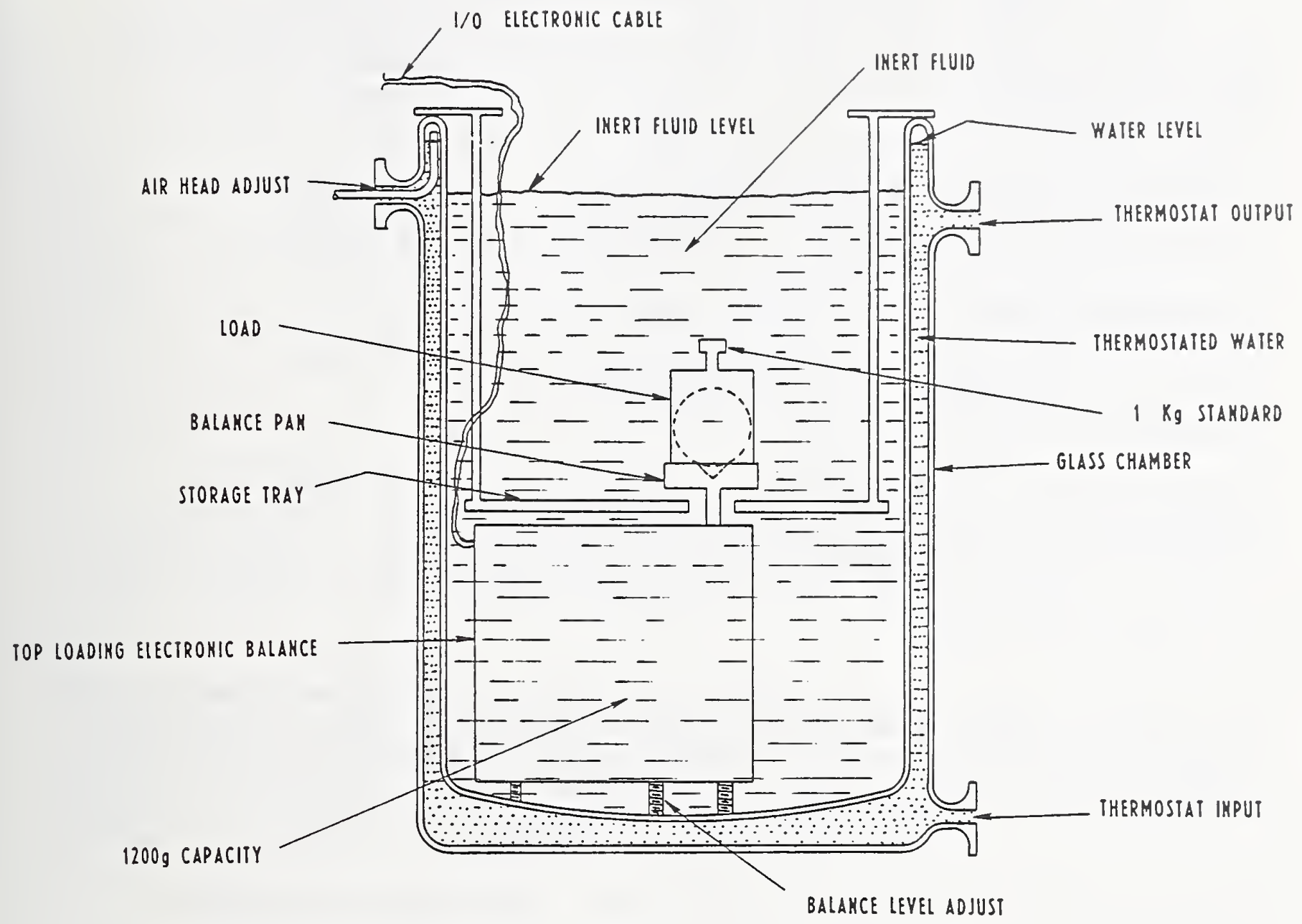

Figure 2. Cross-sectional view of the balance immersed in its thermostated bath. A conventionally-shaped standard weight is shown on the pan. Unconventional loads may also be accommodated by the pan as suggested by the sphere (drawn with dashed lines). 
Table 1. Comparison of Properties of FC-75 and Water

Property (at $25^{\circ} \mathrm{C}$ )

Density $\left(\mathrm{kg} / \mathrm{m}^{3}\right)$

Coefficient of expansion $\left({ }^{\circ} \mathrm{C}^{-1}\right)$

Kinematic viscosity $\left(\mathrm{cm}^{2} / \mathrm{s}\right)$

Vapor pressure $(\mathrm{Pa})$

Surface tension $(\mathrm{N} / \mathrm{m})$

Heat capacity $\left(\mathrm{J} / \mathrm{g}^{-}{ }^{\circ} \mathrm{C}\right)$

Thermal conductivity $\left(\mathrm{W} / \mathrm{cm}^{-}{ }^{\circ} \mathrm{C}\right)$

avalues for FC-75 supplied by the manufacturer.
FC $-75^{a}$

1800

$1.6 \times 10^{-3}$

$0.82 \times 10^{-2}$

4000

0.015

1.0

$1.4 \times 10^{-3}$
Water

1000

$2.5 \times 10^{-4}$

$0.89 \times 10^{-2}$

3200

0.072

4.2

$6.1 \times 10^{-3}$

\subsection{Principles of Use}

We illustrate the use of the submersible balance by finding the volume, $V_{A}$, of an object, $A$, when its mass, $M_{A}$, is known. Placing the object on the balance produces a reading, $0_{A}$, which is related to the other parameters through the equation

$$
O_{A}=K\left[M_{A}-\rho(t) V_{A}(t)\right]
$$

where $\mathrm{O}_{\mathrm{A}}$ is the difference in reading of the loaded and unloaded balance.

Here $\rho$ is the density of the fluorocarbon and $\mathrm{K}$ is a constant scale-factor which may be adjusted by turning a potentiometer controlling the calibration of the balance. Both $\rho$ and $V_{A}$ are functions of the ambient temperature, $t$. In succeeding equations the functional dependence on temperature is not shown explicitly.

Normally $\mathrm{K}$ is adjusted by the balance manufacturer or user so that the balance will read directly the mass of an object of density $8.0 \mathrm{~g} / \mathrm{cm}^{3}$ in air of density $1.2 \times 10^{-3} \mathrm{~g} / \mathrm{cm}^{3}$, i.e. $\mathrm{K}=1.000150$. We found it convenient (though, of course, not essential) to readjust $K$ to exact unity. Thus we can ignore $K$ in the succeeding equations. Hence,

$$
\mathrm{V}_{\mathrm{A}}=\frac{\mathrm{M}_{\mathrm{A}}-\mathrm{O}_{\mathrm{A}}}{\rho}
$$


The problem with using eq (2) is that the precision with which $V_{A}$ can be measured far exceeds the accuracy with which $\rho$ is known. Thus, for best results, one should also measure an object whose mass and volume are known. Placing such an object on the balance essentially calibrates the density of the fluorocarbon at the time of weighing. Let the known object be called S1. Then

$$
\rho=\frac{\mathrm{M}_{\mathrm{S} 1}-\mathrm{O}_{\mathrm{S} 1}}{\mathrm{~V}_{\mathrm{S} 1}}
$$

and

$$
v_{A}=\frac{M_{A}-O_{A}}{M_{S 1}-O_{S 1}} \quad V_{S 1}
$$

In practice, $\mathrm{S} 1$ is a stainless-steel kilogram whose volume has been determined to better than $1 \times 10^{-5}$ by classical hydrostatic weighing. We also include a check standard, S2 in the measurements. The check standard is similar to S1 and similarly calibrated.

\section{Cleaning of Weights}

It is essential that weights being calibrated, as well as the standards used, be clean if the calibration is to be accurate and meaningful. Therefore, a cleaning procedure should be a part of every calibration. [11]

\subsection{Categories of Weights}

For cleaning purposes, weights may be divided into four categories.

1. One-piece weights .

This category will include all one-piece weights except lacquered weights, sheet metal weights and small wire weights.

2. Screw-knob weights.

This category will include all weights with adjusting cavities except lacquered weights.

3. Lacquered weights.

This category includes all lacquered or painted weights.

4. Sheet metal weights and wire weights. 


\subsection{Cleaning Procedures}

\subsubsection{One-Piece Weights}

One-piece weights, 1 gram and larger, are generally steam cleaned. The weights are either held or placed in a jet of steam and manipulated so that the entire surface of the weight is subjected to the cleaning action of the steam long enough to clean it. A superficial steaming is not enough. The weight is then dried, either by evaporation or careful wiping with a soft non-abrasive material free from oil and other substances that will leave a residue on the weights, such as high grade cheesecloth. Care must be exercised that no water spots are left on the weights as they dry. Visible particles on the weights should be brushed or wiped off before steam cleaning them. If a steam generator is not available, one-piece weights may be cleaned either by immersing them in a hot or boiling distilled water bath in a non-metallic container or according to the procedures for screw-knob weights.

Occasionally, a weight will have foreign material adhering to it that requires the use of solvents. Ethyl alcohol is a good general solvent. 4 If alcohol does not remove the material, other solvents may be used, such as benzene, 1,1,1- trichloroethane, etc. Alcohol is then used to remove any film left by the other solvents. The weights are then steam cleaned as outlined above. Cleaning and, in particular, steam cleaning, may adversely affect some alloys. For these alloys, only solvent cleaning is used.

\subsubsection{Screw-Knob Weights}

Weights in this category are usually cleaned by wiping with a soft nonabrasive material, free from oils or other substances that will leave a residue of any kind on the weights, such as high grade cheesecloth. Occasionally, a weight will have foreign matter adhering to it that requires the use of solvents, applied with a cloth. Ethyl alcohol is a good general solvent. If alcohol does not remove the foreign material, other solvents may be used. Alcohol is then used to remove any film left by the other solvents.

To prevent spotting the weights when using solvents, the weights are wiped dry. Care is taken that no liquid gets under the knobs or especially into the adjusting cavity.

A modified steam cleaning procedure may be used on screw-knob weights. The bottoms and sides are steam cleaned, care being taken that no liquid or vapor gets under the knob or into the adjusting cavity.

4 Some solvents are health hazards and should be used in an approved safe manner. 
First, the weights are placed in an acetone bath agitated to help loosen any foreign material. A soft brush, such as a camel hair brush, may be used to agitate the weights. The weights are removed from the acetone, allowed to dry and then steam cleaned. For steam cleaning, the weights are held in front of a jet of steam with forceps until the entire surface has been covered with steam. (See Note on next page.) In order that the portion of the surface under the forceps may be steamed, the weight is set down and picked up again with the forceps holding the weight at a different spot than the first time; the weight is again steamed. The weights are not allowed to touch the steam nozzle. Only a low ash filter paper is used for drying the sheet metal weights. A circular disk is folded unsymmetrically. The main body of the weight is placed between the folds of the paper with the turned edge of the weight protruding. The main body of the weight is dried by pressing lightly on the top of the paper. The turned up edge is brushed lightly with a piece of filter paper. In some cases, it may be necessary to brush the body of the weight with filter paper to remove drops of water. Care must be exercised that no water spots are left on the weights as they dry.

Note: The small fractional weights, say smaller than $5 \mathrm{mg}$, may be placed in a hot or boiling distilled water bath for the final cleaning instead of steam cleaning them. A hot or boiling distilled water bath may also be used for the final cleaning of all sheet metal weights when a steam generator is not available.

\subsection{Temperature Equilibrium}

Newly cleaned weights are allowed to come to temperature equilibrium before they are calibrated. This may take several hours for the larger weights that have been steam cleaned.

Generally, laboratory weights will come to temperature equilibrium over night.

\subsection{Storage}

Usually, weights are not placed in the balance immediately after cleaning, but are stored for varying periods. The weights are stored under cover so that they will stay clean. Weights 1 gram and larger may be stored on a tray lined with filter paper and covered with an inverted glass dish. The smaller weights may be stored in a small glass dish covered with a watch glass. In both cases, the container is labeled with the weight identification.

When the weights are placed in the balance, they are carefully brushed to remove any particles that may be on them. A small bulb type rubber syringe is useful in removing lint and other small particles from weights. The particles are blown off the weights. Therefore, neither the nozzle nor any other part of the syringe need touch the weights. 


\subsection{Brushes}

Brushes require special attention because they are easily contaminated and often are the last cleaning instrument used before the weights are calibrated. Only soft brushes, such as camel hair brushes are used on weights.

The brushes are cleaned by washing with soap and water, then rinsing in ethyl alcohol and allowed to dry in air. New brushes are cleaned before using to remove any oil or other matter that might contaminate the weights. Used brushes are cleaned as often as necessary to be sure that the brushes themselves do not contaminate the weights.

\section{Method of Calibrating Dead Weights}

\subsection{Measurement Algorithm}

The following method of calibrating dead weights--including pressure gage (piston gage) weights--is routinely used [12]. The method employs simple weighing designs and includes corrections for the standards and the buoyant effect of the atmosphere. Calibrations of dead weights are at a lower accuracy than calibrations of mass standards.

The comparisons are made on several different balances whose precision is adequate for the requirements of the weights being tested.

In general, the "Mass Value" of the standard means its True Mass value and its correction means its True Mass Correction unless otherwise indicated.

Measurements are often made on by double-substitution weighing, against the built-in weights of an appropriate single-pan balance. These weights have, in turn, been calibrated against NBS standards. The weighing algorithm is:

1) Read the balance with no load: $S_{1}$

2) Read the balance with unknown on the pan: $D_{1}+S_{2}$

3) Read the balance with unknown \& sensitivity weight: $D_{1}+S_{3}$

4) Read the balance with no load: $S_{4}$

Here $S_{1}$ represents a reading of the angle of tilt of the balance relative to an arbitrary zero and $D_{1}$ represents the nominal values of the summation of dial weights which was used when the balance is loaded. Tare weights are placed on the balance pan as necessary to ensure that the same dial weights are used for operations 2) and 3) (no dial weights are used if no load is on the balance). 
The mass of the unknown is computed to be:

$$
\frac{\mathrm{D}_{1}-\rho \mathrm{V}_{1}+\frac{\Delta-\rho \mathrm{V}_{\Delta}}{\mathrm{S}_{3}-\mathrm{S}_{2}}\left(\mathrm{~S}_{2}-\mathrm{S}_{1}+\mathrm{S}_{3}-\mathrm{S}_{4}\right)}{1-\rho / \mathrm{D}_{\mathrm{x}}}
$$

Where $\mathrm{D}_{1}=$ the calibrated mass of $\mathrm{D}_{1}$

$\mathrm{V}_{1}=$ the volume of $\mathrm{D}_{1}$

$\Delta=$ the mass of the sensitivity weight

$\mathrm{V}_{\Delta}=$ the volume of the sensitivity weight

$D_{\mathrm{X}}=$ the density of the unknown (supplied by the customer)

$\rho=$ the computed density of air in the balance,

\subsection{Uncertainty of Value Assigned to Piston Weights}

It is presumed that the weighings are being carried out by means of a measurement process whose parameters (precision, possible systematic errors, etc.) are known and sufficient evidence is collected to insure that the process is in a state of statistical control.[13] For each method of weighing there is a standard deviation associated with a single measurement of mass difference. This standard deviation is based on considerable history and is used in preference to a standard deviation based on the results of say one day's work. Such a value if available provides the means for judging whether or not to accept that day's measurement as being in control.

The uncertainty of the mass value of the piston weights consists of two parts; the uncertainty due to random errors of measurement and the systematic uncertainty due to the uncertainty in the value of the standard. The limit of the uncertainty due to random errors of measurement may be taken to be three times the standard deviation, $\sigma$, where $\sigma$ is the standard deviation of the process. Therefore:

Uncertainty of value $=3 \sigma+$ uncertainty of standards.

\section{Method of Calibrating Standard Weights}

\subsection{Measurement Algorithm}

An unusual aspect of mass calibrations is that, although the standard is defined at one value, one is typically asked to calibrate a set of weights spanning several decades of mass and, often, not even encompassing the nominal defining value (that is, 1 kilogram). We approach this problem in the following way: 1. The weight in the set of unknowns which is closest in value to $1 \mathrm{~kg}$ is calibrated against an NBS standard of the same nominal value. 2 . 
The rest of the weights in the set are calibrated in a self-consistent manner using the weight calibrated in step 1 as the standard.

It is convenient to calibrate a set of weights a decade at a time, using as a comparator the most sensitive balance available which will accommodate the largest weight in the decade. Table 2 shows the set of balances which we use for nominal values of $1 \mathrm{~kg}$ and below, along with their present standard deviations. Note that we do not calibrate each individual weight in a weight set against a corresponding NBS standard. This would be inefficient. Instead, weights, or summations of weights within the decade are intercompared at several nominal values. The recipe for choosing weights is referred to as a "design". The designs are chosen so that if one of the weights within the design has a known mass value, the mass values of the other weights can be determined. We always pick designs in which we acquire redundant information and calculate the "least squares" values as the calibration result. The least squares solution minimizes the sum of squares of deviations of the predicted minus observed values in much the same way as fitting a series of points on a graph by the least-squares line minimizes the summation of the distances squared of the points from the line. (See Appendix A.)

\subsection{Uncertainty of Value of Standard Weights}

The uncertainties which are assigned to weights which we calibrate result from uncertainties in our starting standards and uncertainties in the comparison of the unknown weights with our starting standards. Typically, random uncertainties dominate the comparison operation. These are usually due to the balance which is serving as the mass comparator.

The specific design which is used also enters into the assignment of uncertainty. One can average a set of repeated measurements to find a better estimated value than from one single measurement. So too, using a weight in the set in more than one measurement results in a standard deviation of the value assigned to the weight which is less than that of a single measurement. How much less depends on the design. Table 3 shows typical calibration uncertainties based on one commonly used metric weight set and a typical design for that weight set. Note that large-valued masses are usually in avoirdupois units (50 $\mathrm{lb}$ and above). The avoirdupois pound is defined as 0.45359237 $\mathrm{kg}$.

One complication of using designs to assign mass values is that the uncertainties assigned to the weights in a set are correlated. This means that when weights are used in combination, the uncertainty of the combination cannot be inferred directly from the uncertainties assigned to each weight individually.

\section{Quality Control}

In the previous section we noted that the total uncertainty in the assignment of mass values to unknown weights comes primarily from uncertainties in the starting standards and random errors in the performance of balances used to 
Table 2. Capacities and standard deviations of balances used

\section{Balance Capacity}

$\begin{array}{rl}3 & \mathrm{~g} \\ 20 & \\ 40 & \\ 160 & \\ 1 & \mathrm{~kg} \\ 10 & \\ 30 & \\ 1 & \mathrm{lb} \\ 6 & \\ 50 & \\ 2500 & \\ 30000 & \end{array}$

\section{Standard Deviation}

$0.0005 \mathrm{mg}$

0.0024

0.0039

0.014

0.032

2.5

8.2

$0.031 \mu \mathrm{lb}$

0.46

$5.5 \mathrm{mg}$

$0.002 \mathrm{lb}$

$0.017 \mathrm{lb}$ 
Table 3. Typical random components of calibration uncertainties

Nom. Val.

$1000 \mathrm{~g}$

500

300

200

100

50

30

20

10

5

3

2

1

$500 \mathrm{mg}$

300

200

100

50

30

20

10

5

3

2

1
Uncertainty

$0.072 \mathrm{mg}$

0.059

0.057

0.050

0.058

0.035

0.029

0.024

0.026

0.013

0.0082

0.0061

0.0049

$0.0026 \mathrm{mg}$

0.0017

0.0012

0.0010

0.00089

0.00087

0.00080

0.00090

0.00083

0.00085

0.00079

0.00090
Nom. Value

$1000 \mathrm{~g}$

$2 \mathrm{~kg}$

3

5

10

20

30
Uncertainty

$0.072 \mathrm{mg}$

6.6

7.8

10.0

15.5

34

55

$\begin{array}{rl}1 & l b \\ 50 & \\ 500 & \\ 2500 & \\ 10000 & 30000\end{array}$

$0.11 \mu \mathrm{lb}$ 22 .

$0.0028 \mathrm{lb}$

0.0073

0.054

0.11 
intercompare the unknowns with the standards. To control the quality of this measurement system, we must insure that the mass of the starting standards does not change and that the random error of the balances used has not deteriorated from its accepted value. In addition, we must have a way to detect simple blunders in data entry. We now describe the controls which are presently in place [14] and outline improvements which are underway.

\subsection{F-Test $[7,13]$}

Every calibration includes a means of checking the balance performance. We assume we know the balance performance based on a large accumulation of data over a long period of time. Each new calibration provides us with another set of data which can be compared with those previously collected. We check to see whether the scatter in the most recent set of data is statistically consistent with the accepted long-term standard deviation of the balance. Failure of this test indicates either a blunder or a sudden degradation of the balance. Figure 3 shows a control chart of the long-term standard deviation of a kilogram balance used in the calibration service. Control limits vary depending on the number of statistical degrees of freedom in a given design. Similar charts are maintained for all the balances used.

\section{2 t-Test $[7,13]$}

Every calibration includes at least two standards along with the unknowns. One standard is used to calibrate both the unknowns and the second standard, which is well-known from many previous measurements. The second standard is called the "check standard" for the following reason: As a result of a calibration, the reference standard is used to assign mass values to the unknowns and the check standard. This mass value of the check standard is then compared to the long-term average of the check standard. A statistically significant difference in the two values indicates a change in the standard, a change in the check standard, or a blunder. Figure 4 is a control chart which shows the long-term variability of the difference in measured mass of our two working kilogram standards. Control charts are also maintained to look for unsuspected variability as a function of ambient temperature, barometric pressure, relative humidity, and air density.

Similar control charts are maintained for all the check standards in use. Occasionally, a check-standard will show a significant change (usually a loss) in mass with time. An example of such behavior is shown in figure 5. The control limits in this case change slowly with time, and are not shown.

Check standards are included in every weighing design. This offers an additional advantage which is best illustrated by an example. Routine calibrations of mass at the $1-\mathrm{kg}$ level begin with starting standards $\mathrm{N} 1$ and $\mathrm{N} 2$. We actually use the total mass of $\mathrm{N} 1$ and $\mathrm{N} 2$ as the starting standard and use the difference in mass between $\mathrm{N} 1$ and $\mathrm{N} 2$ as the check standard. This is a mathematical convenience but is conceptually no different from using $N 1$ as the standard and N2 as the check. While the check standard is adequate for detecting catastrophic changes in $\mathrm{N} 1$ or $\mathrm{N} 2$, it is obviously insensitive to any 


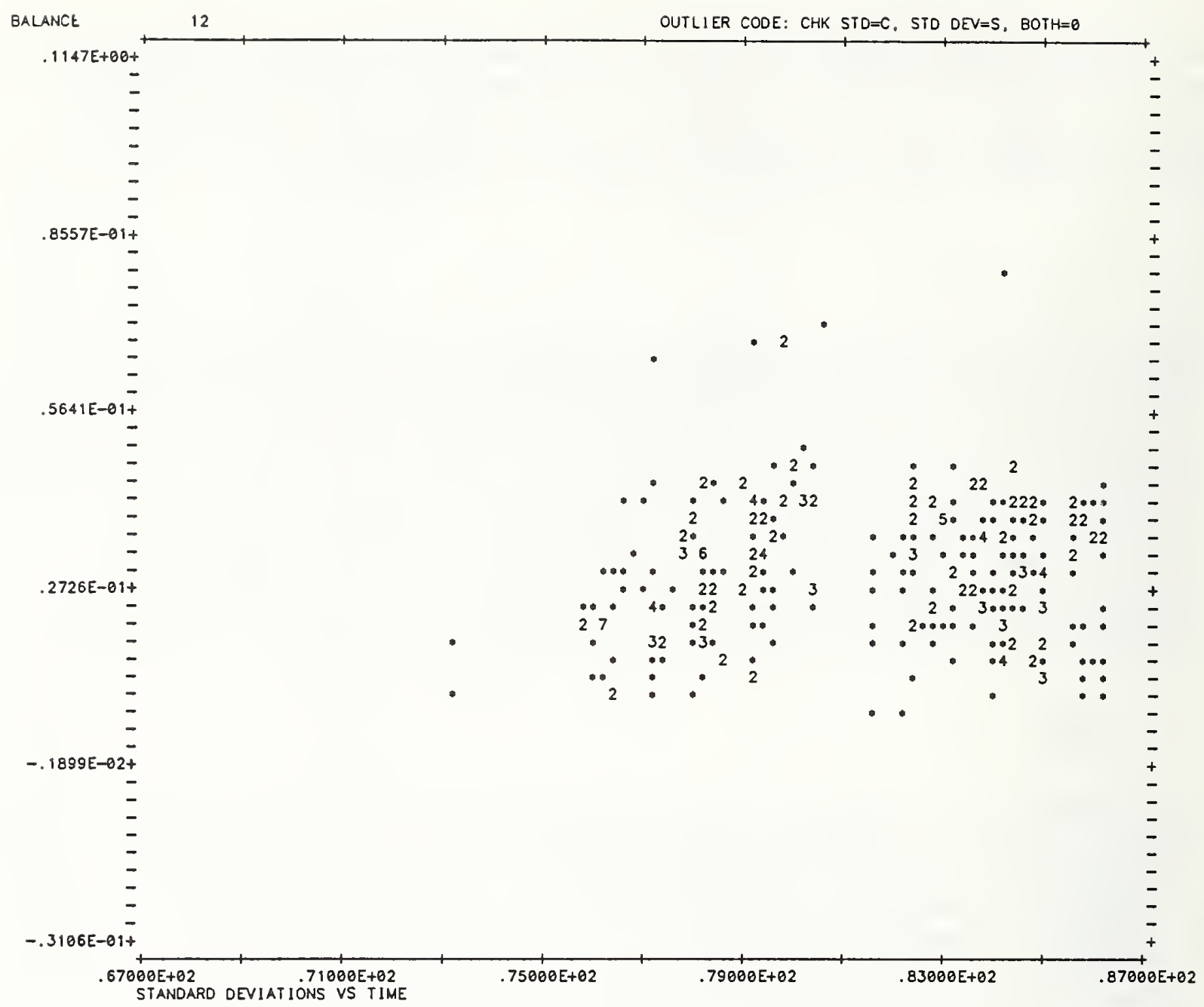

Figure 3. Control chart for the standard deviation of the kilogram balance used in routine mass calibrations. The ordinate gives the measured standard deviation of the balance in milligrams and the abscissa gives the time of the measurement in years since 1900. Control limits are not shown. 


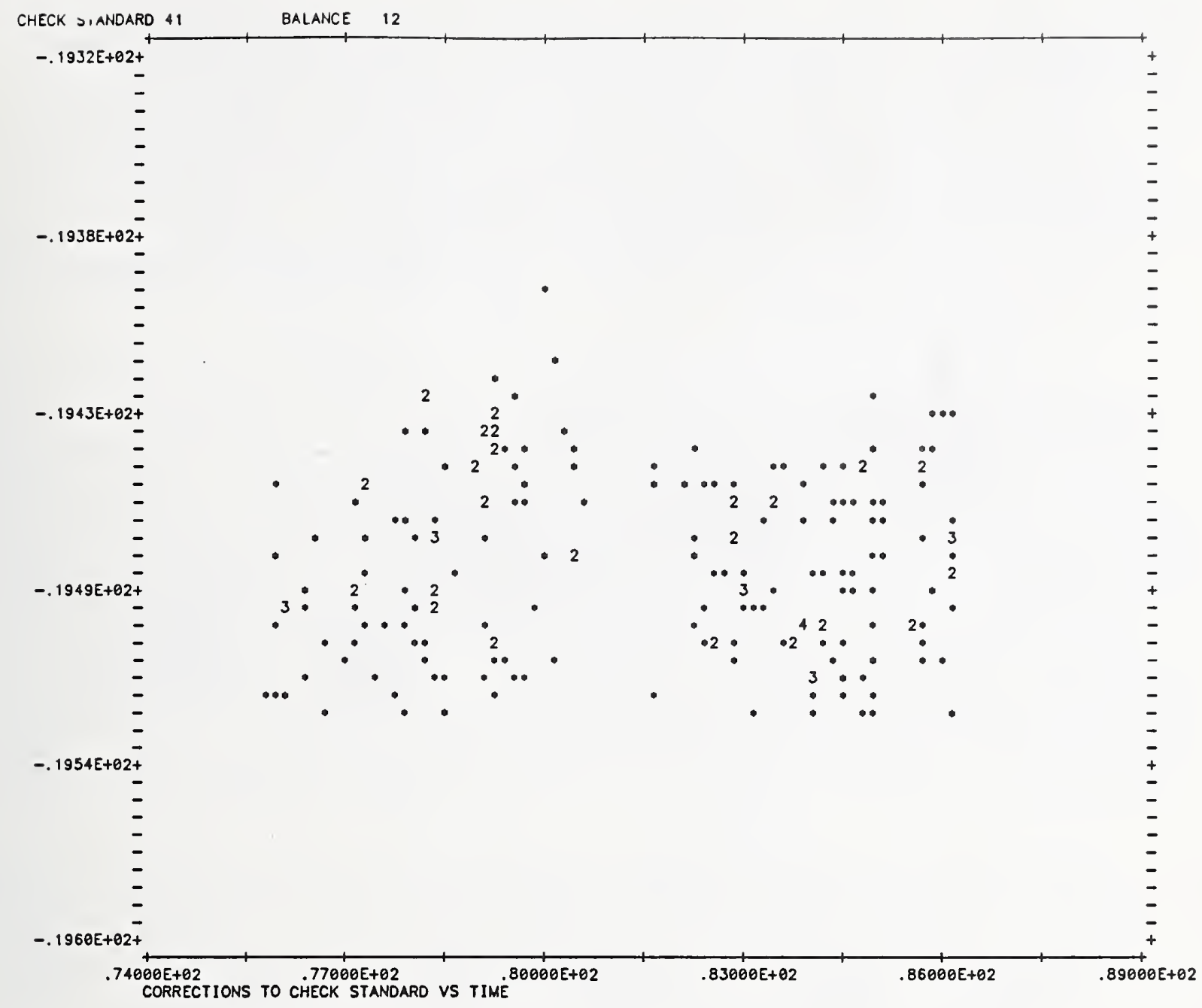

Figure 4. Control chart for the measured difference in mass between kilograms $\mathrm{N} 1$ and $\mathrm{N} 2$. The ordinate is the difference measured in milligrams and the abscissa is the time of the measurement in years since 1900. Control limits are not shown. 


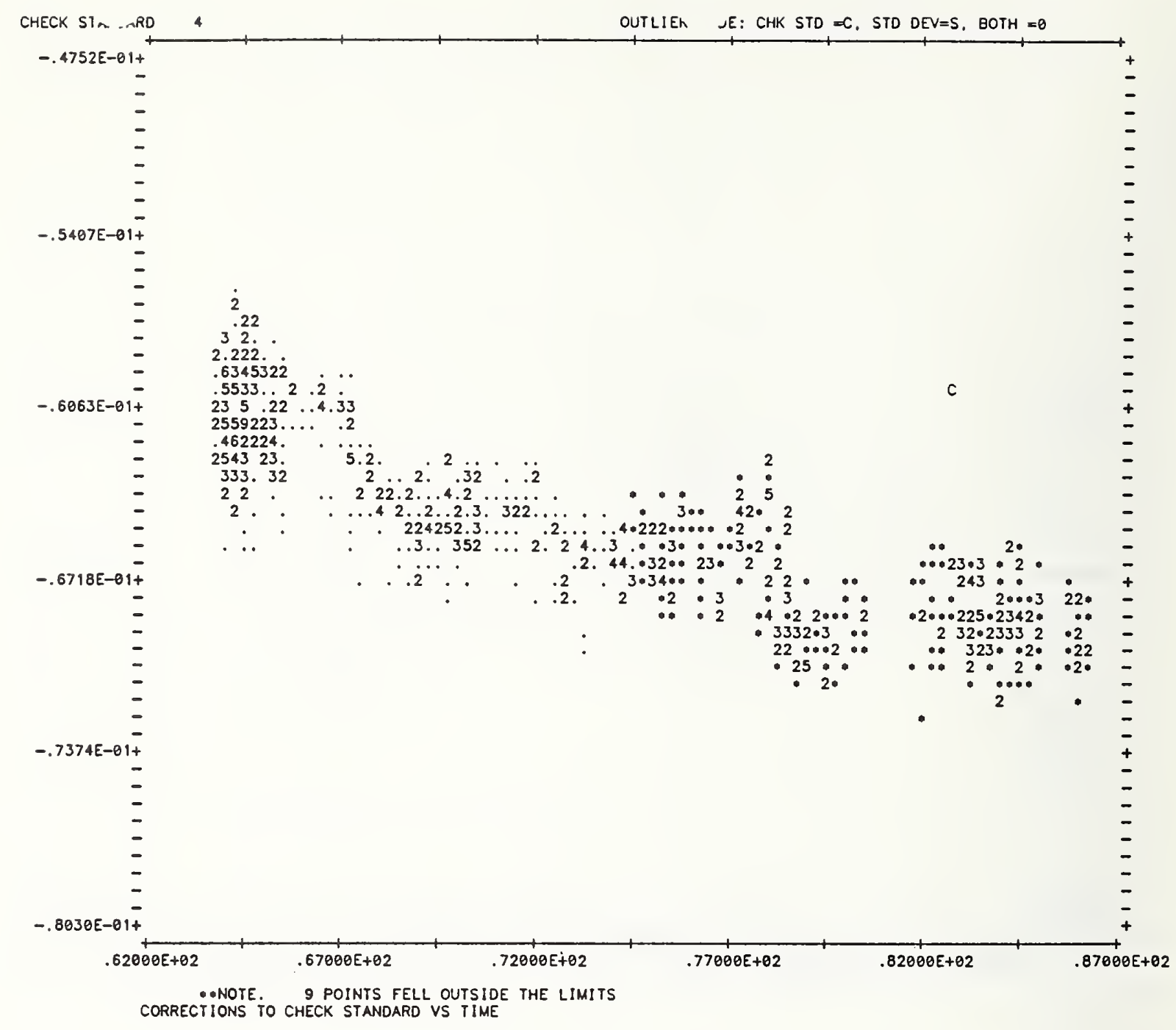

Figure 5. Control chart for the mass of a 1-g check standard. The ordinate is the measured correction to nominal (in milligrams) and the abscissa is the time of the measurement in years since 1900. The check standard is losing mass at the rate of about $0.4 \mathrm{mg} / \mathrm{yr}$. Control limits are not shown. 
processes which change $\mathrm{N} 1$ and $\mathrm{N} 2$ in nearly identical amounts. However, N1 and N2 are used to calibrate weight sets which often include the decade from $1 \mathrm{~kg}$ to $100 \mathrm{~g}$. Every time weights in this decade are calibrated, the results are checked with a $100-\mathrm{g}$ check standard. If there were gross changes in N1 and N2 which nevertheless preserved the value of N1 - N2, they would eventually produce failures of the t-test for the 100-g check standards. The problem, then, is to devise a system which will check the constancy of the starting kilogram standards with enough sensitivity to signal a change before its effect is propagated to other masses.

\subsection{Between-Times Components}

There is a possibility that the standards we are using and measuring have a variability which is a function of time. The shortest time of concern to us is that needed to complete measurements for one design, approximately one hour. We attribute the variability we see in this time scale to the balance (used as comparator) and monitor its constancy by the F-test as described above. A much longer period of interest would be the time between weight calibrations. This is of the order of months or years. The difference between the short-term variability and long-term variability of the measurement process is known as the "between-times" component. We look for the existence of this component by comparing the long-term and short-term standard deviations associated with the check-standards. Ideally, the between-times component will be zero. However, a significant component has been found to exist for calibrations involving the highest relative precision.

For the cases in which we have detected a non-zero between-times component, we have propagated its effect through the calibration process by assuming all weights are subject to the same component as the check standards.

\section{Future Plans}

There are two major weaknesses in our quality controls at present. The first is that the relationship between the SI unit of mass and the unit of mass as embodied by the values assigned to our working kilogram standards $\mathrm{N} 1$ and $\mathrm{N} 2$ is not well-enough determined. Second, the use of the difference in mass of N1 and $\mathrm{N} 2$ as the check standard at the 1-kilogram level is dangerously insensitive to effects common to both kilograms. This is especially disturbing since N1 and N2 are always stored together and receive identical use. A third but less serious problem is that the alloy of which N1 and N2 are made is closer in density to brass than to most commonly used stainless steels. This makes the usual buoyancy corrections more important than they would need to be if the working standards had a density closer to $8.0 \mathrm{~g} \mathrm{~cm}^{-3}$.

To improve these three areas, we have completed or are near to completing the following steps:

1. Six new kilograms weights of nominal density $8.0 \mathrm{~g} \mathrm{~cm}^{-3}$ have been purchased. Their densities have been determined to 10 parts per million by hydrostatic weighing. 
2. An existing kilogram comparator has been reconditioned and partially automated so that its standard deviation is more than 15 times less than that of the comparator used for routine calibrations. Thus, if there were no between-times components, it would require 225 measurements on the less precise balance to achieve the same uncertainty as one measurement on the more precise balance.

3. The two platinum-iridium prototype kilograms of the United States have recently been recalibrated by the International Bureau of Weights and Measures (BIPM) along with two of our stainless-steel working standards. Good internal consistency was obtained between measurements made at NBS and at BIPM. The results show excellent long-term stability of our platinumiridium standards with respect to the SI unit as maintained by the BIPM.

4. An exhaustive series of measurements is underway using our best kilogram comparator. These measurements will establish the long-term stability of our new stainless-steel weights as well as determine how reproducibly they can be cleaned. We have also made preliminary measurements of $\mathrm{N} 1$ and $\mathrm{N} 2$ which can be precisely tied to the SI unit as maintained by the BIPM.

5. When the measurements described in 4. are completed, four of the six new stainless-steel kilograms will be used as working standards. The remaining two will not be used but instead, along with the two stainlesssteel weights which have been calibrated at the BIPM, will serve to monitor the constancy of the working standards thus prolonging the times between calibrations against our platinum-iridium prototypes. 
10. References

[1] Lashof, T. W. and Macurdy, L. B., Precision Laboratory Standards of Mass and Laboratory Weights. NBS Circular 547, Section 1 (1954 August). Reprinted as NBSIR 78-1476 (1978 October).

[2] ASTM E617-81 Standard Specification for Laboratory Weights and Precision Mass Standards, 1986 Annual Book of ASTM Standards, Vol. 14.02: 480-499.

[3] International Organization for Legal Metrology, OIML Recommendation 20 .

[4] Goldman, D. T. and Bell, R. J., eds., The International System of Units (SI): NBS Spec. Publ. 330 (1986 July).

[5] Page, C. H. and Vigoureux, P., eds., The International Bureau of Weights and Measures 1875 - 1975: NBS Spec. Publ. 420 (1975 May).

[6] Davis, R. S., Recalibration of the U.S. National Prototype Kilogram, J. Res. NBS 90 (4), July-August 1985: 263-283.

[7] Jaeger, K. B. and Davis, R. S., A Primer for Mass Metrology, NBS Spec. Publ. 700-1 (1984 November).

[8] Cameron, J. M., Croarkin, M. C., and Raybold, R. C., Designs for the Calibration of Standards of Mass, NBS Tech. Note 952, (1977 June).

[9] Schoonover, R. M. and Davis, R. S., Quick and Accurate Density Determination of Laboratory Weights, Proc. 8th Conf. IMEKO Technical Committee TC3, Krakow Poland, September 9-11, 1980.

[10] Bowman, H. A., Schoonover, R. M. and Carroll, C. L., A Density Scale Based on Solid Objects, J. Res. NBS 78A (1), January-February 1974: $13-40$.

[11] Almer, H. E., Weight Cleaning Procedures, NBSIR 74-443 (1973 November).

[12] Almer, H. E., Method of Calibrating Weights for Piston Gages, NBS Tech. Note 577 (1971 May).

[13] Croarkin, M. C., Measurement Assurance Programs Part II: Development and Implementation, NBS Spec. Publ. 676 II; 1984.

[14] Varner, R. N. and Raybold, R. C., National Bureau of Standards Mass Calibration Computer Software, NBS Tech. Note 1127 (1980 July). 

We begin then with a set of $\mathrm{n}$ observations, $\mathrm{y}_{1}, \mathrm{y}_{2}, \ldots$. . Y $\mathrm{n}$ involving $\mathrm{k}$ objects where values, $\beta_{1}, \beta_{2}, \ldots . \beta_{k}$ are to be determined. The set of observations can be represented by the equations for their expected values, $E\left(y_{i}\right)$,

$$
\begin{aligned}
& \mathrm{E}\left(\mathrm{y}_{1}\right)=\mathrm{x}_{1} \beta_{1}+\mathrm{x}_{12} \beta_{2} \cdot . \cdot \mathrm{x}_{1 \mathrm{k}} \beta_{\mathrm{k}} \\
& \mathrm{E}\left(\mathrm{y}_{2}\right)=\mathrm{x}_{21} \beta_{1}+\mathrm{x}_{22} \beta_{2} \cdot . \cdot \mathrm{x}_{2 \mathrm{k}} \beta_{\mathrm{k}}
\end{aligned}
$$

$$
\mathrm{E}\left(\mathrm{y}_{\mathrm{n}}\right)=\mathrm{x}_{\mathrm{n} 1} \beta_{1}+\mathrm{x}_{\mathrm{n} 2} \beta_{2} \cdot \cdot \cdot \mathrm{x}_{\mathrm{nk}} \beta_{\mathrm{k}}
$$

or in matrix form $\mathrm{E}(\mathrm{y})=\mathrm{x} \beta$ where the element, $\mathrm{x}_{\mathrm{ij}}$, of the $\mathrm{x}$ matrix is 0 if the weight is absent, and 1 or -1 depending on the direction of the comparison. In this note we shall adopt the convention of using just the signs so that, for example, all possible comparisons (ignoring direction) of 4 nominally equal objects will have the representation.

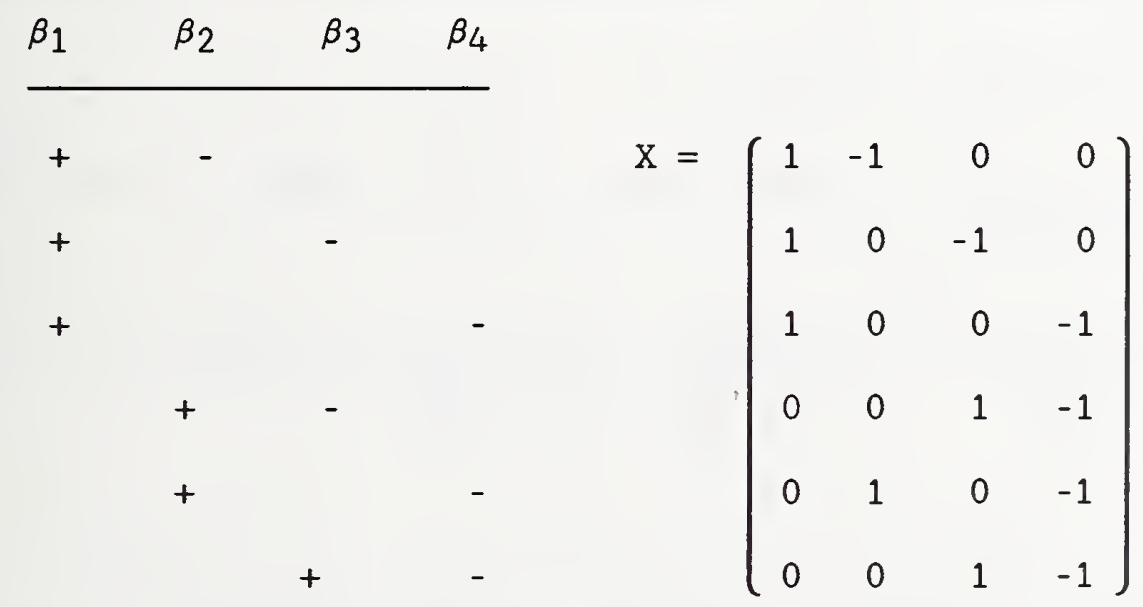

In the least squares analysis one forms the normal equations

$$
\mathrm{x}^{\prime} \mathrm{x} \hat{\beta}=\mathrm{x}^{\prime} \mathrm{y}
$$

where the entries in $X^{\prime} X$ are merely the sums of squares and sums of cross products of the columns of $X$. In the above case, one gets 


$$
\left(\begin{array}{rrrr}
3 & -1 & -1 & -1 \\
-1 & 3 & -1 & -1 \\
-1 & -1 & 3 & -1 \\
-1 & -1 & -1 & 3
\end{array}\right) \hat{\beta}=\quad\left(\begin{array}{l}
y_{1}+y_{2}+y_{3} \\
-y_{1}+y_{4}+y_{5} \\
-y_{2}+y_{4}+y_{5} \\
-y_{3}+y_{4}+y_{6}
\end{array}\right)
$$

where $\hat{\beta}$ is the column vector with elements $\hat{\beta}^{1}, \hat{\beta} 2, \hat{\beta}_{3}, \hat{\beta}_{4}$, the caret being used to denote the fact that the values are functions of the observations, and not the sought-after values, $\beta$.

It can easily be verified in this case that the system of equations is not of full rank (e.g., the column totals are zero) and this is a property of all designs where only differences are measured. In mass calibration, one has one or more standards whose value can be taken as known and these provide the restraint on the system needed to give a unique set of answers. Usually these involve a starting kilogram or a unique summation such as $5+3+2$ which has been determined in a previous series or is the initial unit value for an ascending series such as the $1,2,3,5$ series. One can write the restraint in the form

$$
\mathrm{r}_{1} \beta_{1}+\mathrm{r}_{2} \beta_{2} \ldots+\mathrm{r}_{\mathrm{k}} \beta_{\mathrm{k}}=\mathrm{m}
$$

and use the method of Lagrangian multipliers (with multipliers $2 \lambda$ ) to minimize the function

$$
\left.\Phi=\sum \text { (deviations }\right)^{2}+2 \Sigma\left(\mathrm{r}_{1} \beta_{1}+\ldots \mathrm{r}_{\mathrm{k}} \beta_{\mathrm{k}}-\mathrm{m}\right)
$$

The normal equations now contain an additional "unknown," namely $\lambda$ and written out in full are as follows:

$$
\begin{aligned}
& \sum \mathrm{x}_{1}^{2} \hat{\beta}_{1}+\sum \mathrm{x}_{1} \mathrm{x}_{2} \hat{\beta}_{2} \cdot \sum \mathrm{x}_{1} \mathrm{x}_{\mathrm{k}} \hat{\beta}_{\mathrm{k}}+\mathrm{r}_{1} \lambda=\sum \mathrm{x}_{1} \mathrm{y} \\
& \sum \mathrm{x}_{2} \mathrm{x}_{1} \hat{\beta}_{1}+\sum \mathrm{x}_{2}^{2} \hat{\beta}_{2} \cdot \sum \mathrm{x}_{2} \mathrm{x}_{\mathrm{k}} \hat{\beta}_{\mathrm{k}}+\mathrm{r}_{2} \lambda=\sum \mathrm{x}_{2} \mathrm{y} \\
& \cdot \\
& \cdot \\
& \sum \mathrm{x}_{\mathrm{k}} \mathrm{x}_{1} \hat{\beta}_{1}+\sum \mathrm{x}_{\mathrm{k}} \mathrm{x}_{2} \hat{\beta}_{2} \cdot \sum \mathrm{x}_{\mathrm{k}}{ }^{2} \hat{\beta}_{\mathrm{k}}+\mathrm{r}_{\mathrm{k}} \lambda=\sum \mathrm{x}_{\mathrm{k}} \mathrm{y} \\
& \mathrm{r}_{1} \hat{\beta}_{1}+\mathrm{r}_{2} \hat{\beta}_{2} \cdot \mathrm{r}_{\mathrm{k}} \hat{\beta}_{\mathrm{k}}=\mathrm{m}
\end{aligned}
$$


where

$$
\begin{aligned}
& \sum x_{i} x_{j}=\sum_{k=1}^{n} x_{i k} x_{j k} \\
& \sum x_{i} y=\sum_{k=1}^{n} x_{i k} y_{k}
\end{aligned}
$$

or in matrix notation

$$
\left(\begin{array}{ll}
\mathrm{X}^{\prime} \mathrm{X} & \mathrm{r} \\
\mathrm{r}^{\prime} & 0
\end{array}\right)\left(\begin{array}{l}
\hat{\beta} \\
\lambda
\end{array}\right)=\left(\begin{array}{l}
\mathrm{x}^{\prime} \mathrm{y} \\
\mathrm{m}
\end{array}\right)
$$

The solution may be written out formally as follows:

$$
\left(\begin{array}{l}
\hat{\beta} \\
\lambda
\end{array}\right)=\left(\begin{array}{cc}
\mathrm{C} & \mathrm{h} \\
\mathrm{h}^{\prime} & 0
\end{array}\right)\left(\begin{array}{c}
\mathrm{X}^{\prime} \mathrm{y} \\
\mathrm{m}
\end{array}\right)=\left(\begin{array}{cc}
\mathrm{CX} & \mathrm{h} \\
\mathrm{h}^{\prime} \mathrm{X}^{\prime} & 0
\end{array}\right)\left(\begin{array}{l}
\mathrm{y} \\
\mathrm{m}
\end{array}\right)
$$

To facilitate computation it is convenient to have the values, $\hat{\beta}$, written out as linear functions of the $\mathrm{y}^{\prime} \mathrm{s}$ and $\mathrm{m}, \mathrm{i} . \mathrm{e} ., \beta=\left[\mathrm{CX}^{\prime}, \mathrm{h}\right] \mathrm{y}$. This leads to a set of multipliers of the observations of the form

$$
\begin{aligned}
& \hat{\beta}_{1}=\mathrm{g}_{11} \mathrm{y}_{1}+\mathrm{g}_{12} \mathrm{y}_{2} \cdot \cdot \mathrm{g}_{1 \mathrm{n}} \mathrm{y}_{\mathrm{n}}+\mathrm{h}_{1} \mathrm{~m} \\
& \cdot \\
& \hat{\beta}_{\mathrm{k}}=\mathrm{g}_{\mathrm{k} 1} \mathrm{y}_{1}+\mathrm{g}_{\mathrm{k} 2} \mathrm{y}_{2} \cdot \cdot \mathrm{g}_{\mathrm{kn}} \mathrm{y}_{\mathrm{n}}+\mathrm{h}_{\mathrm{k}} \mathrm{m}
\end{aligned}
$$

These multipliers, $g_{i j}$ and $h_{i}$, are given in Appendix $B$ in transposed form for some of the designs. ${ }^{1}$ The matrix $C$ is important because the variances and covariances of the estimates are given by

$$
\operatorname{Variance}\left(\hat{\beta}_{i}\right)=C_{i i} \sigma^{2} \text {, Covariance }\left(\hat{\beta}_{i}, \hat{\beta}_{j}\right)=C_{i j} \sigma^{2}
$$

The quantity, $\sigma^{2}$, is the variance (square of the long run value of the standard deviation) associated with the process. In a set of $n$ observations on $k$ items and $r=1$ restraints one has $n-k+r=n-k+1$ degrees of freedom for a standard deviation, s, formed by 


$$
\begin{aligned}
& s^{2}=\frac{1}{n-k+1} \sum(\text { deviations })_{i}^{2} \\
& (\text { deviation })_{i}=y_{i}-\left(x_{i 1} \hat{\beta}_{1}+x_{i 2} \hat{\beta}_{2} \cdot \cdot x_{i k} \hat{\beta}_{k}\right)
\end{aligned}
$$

One can write these deviations as a function of the observations by noting that the predicted values are just $\mathrm{X} \beta$ and the deviations are thus

$$
\begin{aligned}
\operatorname{dev} & =y-X \hat{\beta}=y-X\left[C X^{\prime}, h\right]\left(\begin{array}{l}
\mathrm{Y} \\
\mathrm{m}
\end{array}\right)=y-\left[\mathrm{XCX}^{\prime}, 0\right]\left(\begin{array}{l}
\mathrm{Y} \\
\mathrm{m}
\end{array}\right) \\
& =\left[I-\mathrm{XCX}^{\prime}\right] \mathrm{y}
\end{aligned}
$$

which can be written as

$$
\begin{aligned}
& \operatorname{dev}_{1}=d_{11} y_{1}+d_{12} y_{2} \cdot \cdot d_{1 n} y_{n} \\
& \cdot \\
& \operatorname{dev}_{n}=d_{n 1} y_{1}+d_{n 2} y_{2} \cdots \cdot d_{n n} y_{n}
\end{aligned}
$$

The array of coefficients, $d_{i j}$, is given in Appendix $B$ for some of the designs. Weights are often used in combination and one needs to knqw the ștandard deviation for the various sums. For a sum of two items, $\beta_{i}$ and $\beta_{j}$, one has

$$
\operatorname{Var}\left(\hat{\beta}_{i}+\hat{\beta}_{j}\right)=\operatorname{Var}\left(\hat{\beta}_{i}\right)+\operatorname{Var}\left(\hat{\beta}_{j}\right)=2 \operatorname{Cov}\left(\hat{\beta}_{i}, \hat{\beta}_{j}\right)
$$

and for a linear combination

$$
\begin{gathered}
\mathrm{L}=\ell_{1} \hat{\beta}_{1}+\ell_{2} \hat{\beta}_{2} \cdot \cdot \ell_{\mathrm{k}} \hat{\beta}_{\mathrm{k}} \\
\text { Variance }(\mathrm{L})=\ell^{\prime} \mathrm{C} \ell \sigma^{2}
\end{gathered}
$$

where $\ell^{\prime}=\left(\ell_{1} \cdot . \cdot \ell_{k}\right), C$ comes from the inverse of the matrix of normal equations [see eq (6)].

\section{DESIGNS FOR WEIGHING}

The criteria for good weighing designs depend to some extent on the use intended for the resulting values. For example, if the weights are to be used independently of each other, then one would want the standard deviation $\left[\begin{array}{lll}\sigma & C_{i i}\end{array}\right.$ from formula (8)] for the value for each unknown weight to be the minimum possible. If the weights are to be used in combination, then one wants the variance of all appropriate linear functions to be as small as possible. 
Further, the desirability of a design depends somewhat on the restraint being used. In some cases, one's judgment of a design changes depending on whether one starts with a summation as known (e.g., $5+3+2$ ) and works down, or with a unit as known and works up (e.g., by use of a 1,2,3,5 series). 

Appendix B

Sample Calibration Report

The following is a full calibration report for a set of weights with denominations from $1 \mathrm{~g}$ to $1 \mathrm{mg}$. 
U. S. DEPARTMENT OF COMMERCE

NATIONAL BUREAU OF STANDARDS

NATIONAL MEASUREMENT LABORATORY

GAITHERSBURG, MD. 20899

\author{
R E P O \\ O F \\ M A S V V A L U E S
}

COMPANY $X$

LOCUS, U.S.A.

SET OF MASS STANDARDS : 500 MG - 1MG

SERIAL NUMBER 00001

MANUFACIURER : COMPANY Y

SEPTEMBER 1,1986

\title{
TEST NUMBER DEMO 1
}

FOR THE DIRECTOR,

NATIONAL MEASUREMENT LABORATORY

JOE D. SIMMONS, CHIEF

LENGTH AND MASS DIVISION

CENTER FOR BASIC STANDARDS 


\section{INTRODUCT ION}

THIS DOCUMENT IS A COMPREHENSIVE REPORT COVERING THE SEQUENCE OF OPERATIONS USED TO ASSIGN MASS VALUES TO THE WEIGHTS IDENTIFIED ABOVE. IT INCLUDES A COMPLETE DESCRIPTION OF THE MEASUREMENT METHODS AND PROCEDURES WHICH WERE USED, ALL OF THE DATA, AND THE ANALYSIS OF THIS DATA. THE RESULTS ARE PRESENTED IN SEVERAL FORMATS. ASSIGNED MASS VALUES, DISPLACEMENT VOLUMES, COEFFICIENTS OF EXPANSION, UNCERTAINTIES, TOGETHER WITH THE SUMMED VALUES FOR LINEAR COMBINATIONS OF THE WEIGHTS IN EACH DECADE ARE PRESENTED AT THE END OF THE APPROPRIATE SERIES. THIS INFORMATION SHOULD BE USEFUL TO THOSE WHO MUST ASSIGN MASS VALUES TO OBJECTS OTHER THAN WEIGHTS. FOR CONVENIENCE, THE VALUES AND UNCERTAINTIES, TOGETHER WITH OTHER APPROPRIATE DATA AND COMMENTS ARE ALSO SUMMARIZED IN TABLES I AND II AT THE END OF THE REPORT. CERTAIN INTERMEDIATE PAGES ARE SUMMARIES OF STATISTICAL DATA WHICH RELATE TO THE MASS MEASUREMENT PROCESS USED TO PERFORM THIS WORK. THESE PAGES HAVE BEEN LEFT IN THE REPORT TO RETAIN CONTINUITY. COPIES OF THESE PAGES BECOME PART OF A COLLECTION OF STATISTICAL DATA WHICH REFLECTS THE MEASUREMENT PROCESS PERFORMANCE OVER A PERIOD OF TIME. SUCH A COLLECTION HAS BEEN USED TO ESTABLISH THE CONTROL LIMITS FOR ACCEPTING THE RESULTS OF THIS MEASUREMENT. THESE COLLECTIONS ARE OPEN FOR INSPECTION AT OUR FACILITY.

\section{THE MASS MEASUREMENT SYSTEM}

THE MASS MEASUREMENT SYSTEM WITHIN THIS COUNTRY CONSISTS OF ALL OF THE MEASUREMENT PROCESSES
WHICH RELY, DIRECTLY OR INDIRECT LY, ON MASS MEASUREMENTS TO ACCOMPLISH A WIDE VARIETY OF ENDEAVORS. IN ORDER FOR THIS SYSTEM TO FUNCTION PROPERLY, EVERYONE WHO MAKES MEASUREMENTS MUST BE ABLE TO VERIFY THAT HIS MEASUREMENT PROCESS PRODUCES CONSISTENT RESULTS WHICH ARE COMPATIBLE WITH HIS PARTICULAR REQUIREMEN TS. THE WEIGHTS COVERED BY THIS REPORT, TOGETHER WITH THE ASSIGNED VALUES AND THE APPROPRIATE UNCERTAINTIES FOR THESE VALUES, PROVIDE IN PART A BASIS FOR CONSISTENT MEASUREMENTS WITHIN THIS SYSTEM OF RELATED MEASUREMENT PROCESSES.

APPROPRIATE CHARACTERIZATION OF ANY MEASUREMENT PROCESS IS FUNDAMENTAL TO VERIFYING THAT RESULTS ARE CONSISTENT WITH THE END REQUIREMENT WITH RESPECT TO CORRECTNESS AND ECONOMY OF THE MEASUREMENT EFFORT. WITHOUT THIS INFORMATION, THE BENEFITS OF OWNERSHIP OF THESE WEIGHTS MAY BE COMPLETELY ILLUSORY. THE ASSIGNED UNCERTAINTIES IN THIS REPORT ARE DESCRIPTIVE OF OUR MASS MEASUREMENT PROCESS. EFFECTIVENESS OF THE TRANSFER OF THE UNIT FROM ONE FACILITY TO ANOTHER SHOULD BE VERIFIED BY AN INDEPENDENT TEST. IT IS PRESUMED THAT THESE WEIGHTS WILL BE USED IN A SIMILARLY WELLCHARACTERIZED MEASUREMENT PROCESS SO THAT THE STATISTICAL PARAMETERS OF BOTH PROCESSES CAN BE COMBINED TO PROVIDE A REALISTIC ESTIMATE OF THE UNCERTAINTY OF THE MASS UNIT AS ACTUALLY REALIZED IN ANOTHER FACILITY. A COMPREHENSIVE SERVICE DIRECTED TOWARD THE EVALUATION OF A PARTICULAR MASS MEASUREMENT PROCESS IS AVAILABLE THROUGH THE MASS MEASUREMENT ASSURANCE PROGRAM OF THE NATIONAL BUREAU OF STANDARDS. 
LOCUS, U.S.A.

SET OF MASS STANDARDS : 500 MG - 1MG

TEST NUMBER DEMO 1

\section{WEIGHING DESIGN}

ONLY DIFFERENCES IN MASS CAN BE MEASURED, THEREFORE THE MASS VALUES FOR THE 'UNKNOWN' WEIGHTS MUST BE DETERMINED BY COMPARISON WITH OTHER WEIGHTS WHICH HAVE ACCEPTED MASS VALUES. THE 'UNKNOWN' WEIGHTS TOGETHER WITH 'CHECK STANDARDS', ARE GROUPED AND INTERCOMPARED ACCORDING TO THE DESIGN SCHEDULE GIVEN AT THE BEGINNING OF EACH SERIES OF WEIGHINGS. THE FIRST SERIES CONTAINS STANDARDS WHICH PROVIDE THE STARTING VALUES FOR THE SERIES OF WEIGHINGS AND PROVIDE THE TIE POINT FOR CONSISTENCY THROUGHOUT THE MEASUREMENT SYSTEM. THE WEIGHING METHOD USED, I.E., DOUBLE SUBSTITUTION, TRANSPOSITION, ETC. IS INDICATED ALONG WITH THE OBSERVED DATA. IN THE COMPUTATIONS, THE DISPLACEMENT VOLUMES ARE TREATED EXPLICITLY, USING THE DATA LISTED IN THE REPORT. IN ALL CASES, A REDUNDANCY IN THE NUMBER OF MEASUREMENTS PROVIDES A MEANS FOR CHECKING ON THE PRECISION OF THE PROCESS.

WHEN THERE ARE MORE EQUATIONS THAN 'UNKNOWNS', NOT ALL OBSERVATIONAL EQUATIONS CAN BE SATISFIED EXACTLY AND THE METHOD OF LEAST SQUARES IS USED TO PROVIDE ESTIMATES OF THE 'UNKNOWN' VALUES. THIS METHOD LEADS TO ESTIMATORS WHICH ARE LINEAR FUNCTIONS OF THE DATA AND WHICH HAVE STANDARD DEVIATIONS READILY CALCULATED FROM THE COEFFICIENTS OF THE LINEAR FUNCTIONS AND THE STANDARD DEVIATION OF AN INDIVIDUAL MEASUREMENT. THE 'CHECK STANDARD' IS ALSO TREATED AS AN UNKNOWN AND THE AGREEMENT OF THE CURRENT RESULT WITH THE ACCEPTED VALUE PROVIDES A TEST OF THE ADEQUACY OF THE CURRENT DATA. THIS SAME CHECK
STANDARD IS MEASURED WITH EACH TEST OF UNKNOWNS AND THE COLLECTION OF VALUES OVER TIME IS USED TO EVALUATE THE PERFORMANCE OF THE MEASUREMENT PROCESS.

IN THE CASE OF THE SERIES WHICH INCLUDES THE KNOWN STANDARDS, THE ACCEPTED VALUES OF THESE STANDARDS SERVE AS A RESTRAINT ON THE SOLUTION OF THE EQUATIONS FOR THE VALUES OF ALL OF THE WEIGHTS. THE RESTRAINT FOR THE SOLUTION OF SUBSEQUENT SERIES IS PROVIDED BY THE VALUES ESTABLISHED FOR ONE OR MORE WEIGHTS INCLUDED IN A PREVIOUS SERIES.

ESTIMATED VALUES FOR WEIGHTS WHICH HAVE BEEN GROUPED IN THE SAME SERIES INVOLVE THE SAME OBSERVATIONAL DATA AND ARE, IN ALMOST ALL CASES, CORRELATED. FOR EACH SERIES THERE IS A TABLE OF COMBINATIONS TOGETHER WITH THE APPROPRIATE UNCERTAINTY FOR EACH COMBINATION.

PROCESS CONTROL

THE STANDARD DEVIATION, AS COMPUTED FROM THE LEAST SQUARES SOLUTION, PROVIDES A CHECK ON THE SHORT TERM, OR 'WITHIN-RUN' PROCESS PRECISION. AN AVERAGE OF A NUMBER OF THESE STANDARD DEVIATIONS IS TAKEN AS THE ACCEPTED WITHIN-RUN STANDARD DEVIATION OF THE PROCESS AND IS USED AS A REFERENCE VALUE FOR SURVEILLANCE OF THE PROCESS PRECISION. THE VALUES OBTAINED FOR THE' CHECK STANDARD' PROVIDE, AS TIME GOES ON, A SEQUENCE OF VALUES THAT REALISTICALLY REFLECTS THE VARIATIONS WHICH BESET PRECISE MEASUREMENTS. COLLECTIONS OF VALUES FOR BOTH THE WITHIN-RUN PRECISION AND THE VALUE OBTAINED FOR THE 'CHECK STANDARD' SHOULD 
SET OF MASS STANDARDS : 500 MG - 1MG TEST NUMBER DEMO1

POSSESS THE PROPERTIES OF RANDOMNESS ASSOCIATED WITH INDEPENDENT MEASUREMENTS FROM A STABLE PROBABILITY DISTRIBUTION. THE REPORTED 'F RATIO' AND 'T VALUE' ARE TESTS OF THE VALUES FROM THE CURRENT RUN FOR CONFORMITY TO THEIR RESPECTIVE DISTRIBUTIONS AND IF SATISFACTORY ARE TAKEN AS EVIDENCE THAT THE PROCESS IS IN CONTROL AND THAT PREDICTIVE STATEMENTS REGARDING UNCERTAINTY ARE VALID.

CONTROL CHARTS ON THE WITHINRUN PROCESS PRECISION AND THE VALUES OBTAINED FOR THE CHECK STANDARD ARE KEY ELEMENTS IN MONITORING THE STATE OF CONTROL OF ANY PRECISE MASS MEASUREMENT PROCESS. IN ADDITION TO PROVIDING A BASIS FOR JUDGMENT AS TO THE ADEQUACY OF A GIVEN PROCESS FOR A PARTICULAR REQUIREMENT, THESE DATA PROVIDE A MEANS TO JUDGE THE IMPORTANCE OF LONG TERM, OR 'BETWEEN-RUN' VARIABILITY WHICH CAN BE CHARACTERIZED BY THE STANDARD DEVIATION OF THE VALUES ABOUT THE MEAN. IF THERE IS AN ADDITIONAL COMPONENT OF VARIANCE ENTERING FROM RUN TO RUN, THIS STANDARD DEVIATION WILL BE LARGER THAN CAN BE ACCOUNTED FOR BY THE WITHIN-RUN VARIABILITY. CORRELATION STUDIES, AS WELL AS SUPPLEMENTAL EXPERIMENTS, ARE USED TO DETECT AND REDUCE THE MAGNITUDE OF SIGNIFICANT SYSTEMATIC EFFECTS. APPROPRIATE ACTION, E.G., ADDITIONAL EMPIRICAL CORRECTIONS OR CHANGES IN TECHNIQUE, CAN REDUCE THE EFFECTS FROM KNOWN SOURCES OF SYSTEMATIC VARIABILITY TO A MAGNITUDE WHICH IS NO LONGER IDENTIFIABLE IN THE DATA. IN THE CASES WHERE A SIGNIFICANT LONG TERM, OR BETWEEN-RUN, COMPONENT REMAINS THE UNCERTAINTY HAS BEEN APPROPRIATELY ADJUSTED.
SERIES OF MEASUREMENTS JUDGED AS OUT OF CONTROL RELATIVE TO THE APPROPRIATE PARAMETER ARE CARE FULLY EXAMINED. IF RERUNS WERE NECESSARY IN THE COURSE OF THIS WORK, THE 'OUT OF CONTROL' SERIES, WITH REMARKS AS APPROPRIATE, ARE ATTACHED AT THE END OF THE REPORT FOR YOUR INFORMATION.

\section{UNCERTAINTY}

IT IS ASSUMED THAT THE PRESENT 'ACCEPTED VALUES' OF TWO NBS STANDARDS AT THE 1 KILOGRAM LEVEL, DESIGNATED N1 AND N2, ARE WITHOUT ERROR. ESTIMATES OF THE UNCERTAINTY OF THE ACCEPTED VALUES OF THE NBS STANDARDS RELATIVE TO THE INTERNATIONAL PROTOTYPE KILOGRAM CAN BE PROVIDED ON REQUEST. HOWEVER, THESE ESTIMATES HAVE NO REAL MEANING IN EITHER NATIONAL OR INTERNATIONAL COMPARISON. THIS IS BECAUSE OF THE LACK OF SUFFICIENT DATA TO PROVIDE A REALISTIC ESTIMATE OF THE UNCERTAINTY IN THE VALUES ASSIGNED TO THE PROTOTYPE KILOGRAMS K20 AND K4, PARTICULARLY IN REGARD TO LONG TERM, OR BETWEEN-RUN VARIABILITY. CHANGES IN THE ACCEPTED VALUES FOR THE NBS STANDARDS AT THE KILOGRAM LEVEL, AS AND WHEN THEY OCCUR, WILL BE REPORTED IN THE SCIENTIFIC PAPERS OF THE BUREAU AND WILL BE GIVEN WIDE DISTRIBUTION. IN CASES WHERE SUCH CHANGES MAY BE OF IMPORTANCE, OR WHERE CONTINUITY IS DESIRED, INSTRUCTIONS WILL BE INCLUDED FOR UP-DATING PREVIOUSLY REPORTED VALUES. WHEN THE VALUES REPORTED ARE BASED ON THE ACCEPTED VALUES OF STANDARDS OTHER THAN STANDARDS N1 AND N2 MENTIONED ABOVE, THE UNCERTAINTY OF THE ACCEPTED VALUE OF THE STANDARD BECOMES A SYSTEMATIC ERROR IN THE ASSIGNMENT OF VALUES TO OTHER STANDARDS AND IS INCLUDED IN THE REPORT. 
LOCUS, U.S.A.

SET OF MASS STANDARDS : 500 MG - 1MG

TEST NUMBER DEMO1

A BALANCE UNDER STABLE OPERATING CONDITIONS WILL EXHIBIT A CERTAIN CHARACTERISTIC VARIABILITY WHICH CAN BE DESCRIBED BY THE STANDARD DEVIATION FOR SUCH MEASUREMENTS. TRE VALUE FOR A PARTICULAR WEIGHT DETERMINED IN REPEATED TESTS WITH THE SAME WEIGHING DESIGN WILL BAVE ITS OWN STANDARD DEVIATION WHICH WILL BE SOME FUNCTION OF THE BALANCE PRECISION AND (POSSIBLY) OF THE BETWEEN-RUN COMPONENT. AS AN OUTER LIMIT OF THE DISTRIBUTION OF RANDOM ERRORS, THREE TIMES THE STANDARD DEVIATION IS USED. SYSTEMATIC ERRORS DUE TO THE PROCEDURES USED OR TO ENVIRONMENTAL EFFECTS ARE LARGELY BALANCED OUT AND CAN USUALLY BE REGARDED AS NEGLIGIBLE. WHEN A NON-NEGLIGIBLE BOUND TO THE POSSIBLE EFFECT FROM KNOWN SOURCES IS AVAILABLE, IT IS CALCULATED AND REPORTED SEPARATELY, E.G., THE UNCERTAINTY OF ACCEPTED VALUE AT OTHER THAN THE 1 KILOGRAM LEVEL. THE DISTRIBUTION IMPLIED BY THE RANDOM ERRORS MAY THUS BE CENTERED SOMEWHERE IN THE RANGE GIVEN BY THE BOUNDS TO THE SYSTEMATIC ERROR. THE TOTAL UNCERTAINTY IS TAKEN AS THE SUM OF THESE TWO COMPONENTS

THE UNCERTAINTY ASSOCIATED WITH THE ASSIGNED VALUE CAN BE THOUGHT OF AS A BOUND TO THE DEPARTURE OF THE ASSIGNED VALUE FROM A HYPOTHETICAL AVERAGE VALUE THAT WOULD BE OBTAINED IF IT WERE POSSIBLE TO REPEAT THE MEASUREMENT MANY TIMES OVER A WIDE VARIETY OF CONDITIONS, E.G., SUBSTITUTE THE WEIGHT FOR ONE OF THE CHECK STANDARDS. THIS MEANS THAT THE UNCERTAINTY BAND CENTERED ON THE VALUES OBTAINED FROM EACH OF TWO MEASUREMENTS OF THE SAME OBJECT OVER SOME ARBITRARY TIME INTERVAL
SHOULD ALMOST ALWAYS OVERLAP. IN OTHER WORDS, WHILE A SECOND MEASUREMENT WILL PRODUCE A DIFFERENT VALUE, THIS VALUE WILL ONLY RARELY DIFFER FROM THE FIRST VALUE BY MORE THAN THE SUM OF THE TWO UNCERTAINTIES. THE UNCERTAINTY BANDS ARE NOT EXPECTED TO OVERLAP IF SOME EVENT HAS OCCURRED IN THE TIME INTERVAL BETWEEN THE TWO MEASUREMENTS WHICH WILL CHANGE THE MASS OF THE OBJECT, E.G., ABRASIONS, ABUSE, CORROSION, IMPROPER CLEANING AND THE LIKE.

THE UNCERTAINTY IN ASSIGNED VALUE CONTAINED IN THIS REPORT BECOMES A SYSTEMATIC EFFECT FOR THE MEASUREMENT PROCESS IN WHICH THESE WEIGHTS ARE TO BE USED. IN THE ABSENCE OF OTHER SIGNIFICANT SYSTEMATIC EFFECTS IN THE USER'S MEASUREMENT PROCESS (A CONDITION WHICH MUST BE DEMONSTRATED) THE UNCERTAINTY OF THE VALUE ASSIGNED BY THE USER IS AN APPROPRIATE COMBINATION OF THE SYSTEMATIC ERROR IN THE STANDARD AND THE RANDOM COMPONENT ASSOCIATED WITH HIS PROCESS. IF THE MEASUREMENT PROCESSES ARE IN CONTROL AND APPROPRIATE UNCERTAINTIES ARE ASSIGNED, THE VALUES PRODUCED BY DIFFERENT MEASUREMENT FACILITIES WILL BAVE OVERLAPPING UNCERTAINTY BANDS AS DESCRIBED ABOVE. ONE CANNOT DISCUSS DIFFERENCES IN VALUES FOR THE SAME OBJECT OBTAINED BY DIFFERENT FACILITIES WITH ANY DEGREE OF SERIOUSNESS UNLESS EACH VALUE IS ACCOMPANIED BY A REALISTIC UNCERTAINTY STATEMENT. 
SET OF MASS STANDARDS : 500 MG - 1 MG

TEST NUMBER DEMO1

\section{REFERENCES}

THE FOLLOWING REFERENCES ARE SUGGESTED FOR DETAILED DESCRIPTION OF PORTIONS OF THIS REPORT, AND FOR GENERAL INFORMATION CONCERNING THE MASS MEASUREMENT PROCESS:

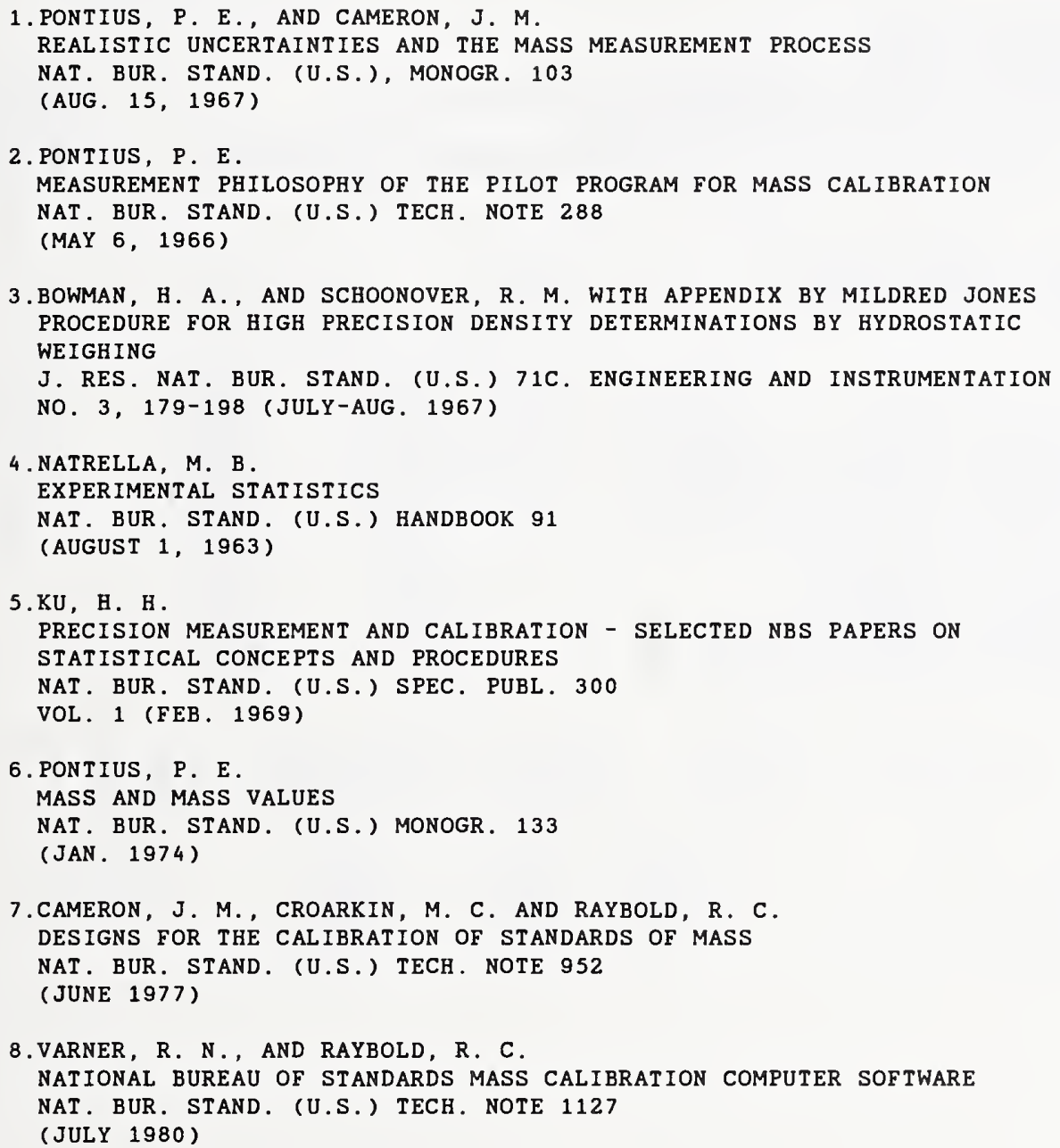


BALANCE 2

OPERATOR 39

ACCEPTED WITHIN STANDARD DEVIATION OF THE PROCESS

ACCEPTED BETWEEN STANDARD DEVIATION OF THE PROCESS

$0.00240 \mathrm{MG}$

$0.00000 \mathrm{MG}$

CALIBRATION DESIGN

$\begin{array}{lllll}\text { RESTRAINT VECTOR } & 1 & 0 & 0 & 0\end{array}$

MASS CORRECTION OF RESTRAINT

VOLUME OF WEIGHTS BEING USED IN RESTRAINT AT 22.92

SYSTEMATIC ERROR IN THE RESTRAINT

22.92

3 STANDARD DEVIATION LIMIT FOR RANDOM ERROR AFFECTING RESTRAINT
$-0.06971 M G$
$0.11990 \mathrm{CM} 3$
$0.00087 \mathrm{MG}$
$0.00000 \mathrm{MG}$

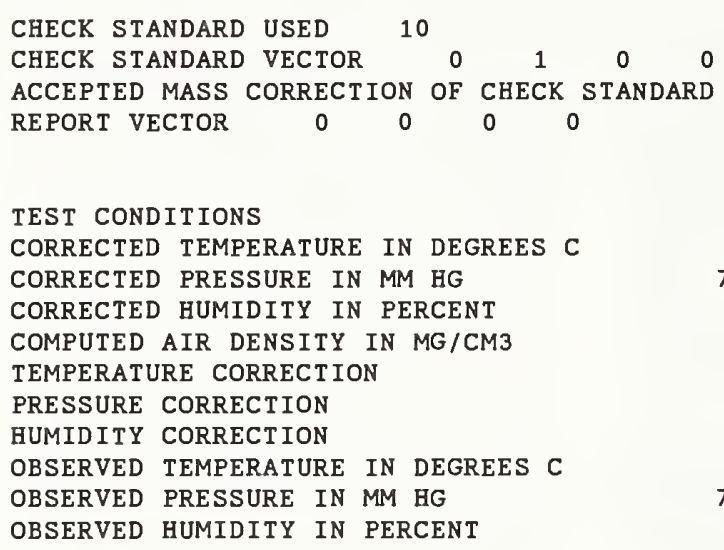

BEFORE
22.85
759.028
27.50
1.1883
0.00
-0.172
0.00
22.85
759.200
27.50

AFTER
23.00
758.828
27.30
1.1874
0.00
-0.172
0.00
23.00
759.000
27.30

-0.00740 MG

$\begin{array}{lllccr} & \begin{array}{c}\text { WEIGHTS BEING } \\ \text { TESTED }\end{array} & \begin{array}{c}\text { NOMINAL } \\ \text { VALUE G }\end{array} & \begin{array}{c}\text { DENSITY } \\ \text { G/CM3 AT 20C }\end{array} & \begin{array}{c}\text { COEFFICIENT } \\ \text { OF EXPANSION }\end{array} & \begin{array}{c}\text { ACCEPTED } \\ \text { CORRECTION MG }\end{array} \\ \text { NB } & 1 \mathrm{G} & 1.0000 & 8.3406 & .000040 & -0.06971 \\ \text { AA } & 1 \mathrm{G} & 1.0000 & 7.8704 & .000045 & -0.00740 \\ & 1 \mathrm{G} & 1.0000 & 8.4000 & .000054 & \\ \text { SUM } & 1 \mathrm{G} & 1.0000 & 16.6000 & .000020 & \end{array}$


COMPANY $X$

LOCUS, U.S.A.

SET OF MASS STANDARDS : 500 MG - 1MG TEST NUMBER DEMO1

BALANCE 2

OPERATOR 39

CALIBRATION DESIGN 41 GRAMS

$\begin{array}{llllll} & & 1 & 1 & 1 & 1 \\ \text { A } & 1 & + & - & & \\ \text { A } & 2 & + & & - & \\ \text { A } & 3 & + & & & - \\ \text { A } & 4 & & + & - & \\ \text { A } & 5 & & + & & - \\ \text { A } & 6 & & & + & - \\ \text { R } & & + & & & \end{array}$

OBSERVATIONS IN DIVISIONS

DOUBLE SUBSTITUTION ONE PAN BALANCE

$\begin{array}{llllll}\mathrm{A} & 1 & 8.1660 & 8.2200 & 13.2310 & 13.1810 \\ \mathrm{~A} & 2 & 8.1680 & 8.2030 & 13.2160 & 13.1840 \\ \mathrm{~A} & 3 & 8.1690 & 8.1500 & 13.1650 & 13.1840 \\ \mathrm{~A} & 4 & 8.2160 & 8.2060 & 13.2150 & 13.2340 \\ \mathrm{~A} & 5 & 8.2200 & 8.1500 & 13.1620 & 13.2350 \\ \mathrm{~A} & 6 & 8.2010 & 8.1460 & 13.1630 & 13.2100\end{array}$

PAGE 7 SERIES 1 $8 / 29 / 86$ 
COMPANY $X$

LOCUS, U.S.A.

SET OF MASS STANDARDS : 500 MG - IMG

PAGE 8

SERIES 1

TEST NUMBER DEMO 1

BALANCE 2

OPERATOR 39

CALIBRATION DESIGN 41

SENSITIVITY WEIGHT

MASS 4.99198 MG

VOLUME 0.00185 CM3 AT $20 \mathrm{C}$

COEFFICIENT OF EXPANSION 0.000069 $\mathrm{S}^{*}=\mathrm{S}-\mathrm{PV}(\mathrm{S})=\quad 4.98978 \mathrm{MG}$

\begin{tabular}{|c|c|c|c|c|c|}
\hline & $\begin{array}{l}A(I) \\
(M G)\end{array}$ & $\begin{array}{c}\operatorname{DELTA}(I) \\
(M G)\end{array}$ & $\begin{array}{l}\text { AVERAGE } \\
\text { SENSITIVITY } \\
\text { (MG/DIV) }\end{array}$ & $\begin{array}{l}\text { DRIFT (I) } \\
\text { (MG) }\end{array}$ & $\begin{array}{l}\text { OBSERVED } \\
\text { SENSITIVITY } \\
\text { (MG/DIV) }\end{array}$ \\
\hline 1 & -0.05177 & -0.00087 & 0.99558 & 0.00199 & 0.99616 \\
\hline 2 & -0.03335 & 0.00062 & 0.99558 & 0.00149 & 0.99567 \\
\hline 3 & 0.01892 & 0.00025 & 0.99558 & 0.00000 & 0.99497 \\
\hline 4 & 0.01444 & -0.00249 & 0.99558 & 0.00448 & 0.99706 \\
\hline 5 & 0.07118 & 0.00162 & 0.99558 & 0.00149 & 0.99587 \\
\hline 6 & 0.05077 & -0.00187 & 0.99558 & -0.00398 & 0.99378 \\
\hline
\end{tabular}

$\begin{array}{lccccc}\text { ITEM } & \text { CORRECTION } & \begin{array}{c}\text { VOLUME } \\ \text { (AT T) } \\ \text { (G) }\end{array} & \begin{array}{c}\text { SYSTEMATIC } \\ \text { (MRROR }\end{array} & \begin{array}{c}\text { 3 S.D. } \\ \text { LIMIT } \\ \text { (MG) }\end{array} & \begin{array}{c}\text { UNCERTAINT } \\ \text { LIMIT } \\ \text { (MG) }\end{array} \\ 1.0000 & -0.06971 & 0.11990 & 0.00087 & 0.00000 & 0.00087 \\ 1.0000 & -0.01029 & 0.12707 & 0.00087 & 0.00509 & 0.00596 \\ 1.0000 & -0.03673 & 0.11906 & 0.00087 & 0.00509 & 0.00596 \\ 1.0000 & -0.15925 & 0.06023 & 0.00087 & 0.00509 & 0.00596\end{array}$

TEMPERATURE $\mathrm{T}=22.92 \mathrm{C}$

RESTRAINT FOR FOLLOWING SERIES

$\begin{array}{lllrl}\text { RESTRAINT VECTOR } & 0 & 0 & 0 & 1 \\ \text { MASS CORRECTION } & & & -0.15925 \text { MG } \\ \text { VOLUME AT 20 C } & & & 0.06023 \text { CM3 } \\ \text { SYSTEMATIC ERROR } & & & 0.00087 \text { MG } \\ \text { 3 STANDARD DEVIATION LIMIT } & & 0.00509 \text { MG }\end{array}$


COMPANY $X$

PAGE 10

LOCUS, U.S.A.

SET OF MASS STANDARDS : 500 MG - 1MG

SERIES 2

TEST NUMBER DEMO 1

$8 / 29 / 86$

BALANCE 13

OPERATOR 39

ACCEPTED WITHIN STANDARD DEVIATION OF THE PROCESS

$0.00050 \mathrm{MG}$

ACCEPTED BETWEEN STANDARD DEVIATION OF THE PROCESS

$0.00000 \mathrm{MG}$

CALIBRATION DESIGN 62

$\begin{array}{lllllll}\text { RESTRAINT VECTOR } & 1 & 1 & 1 & 0 & 0 & 0\end{array}$

MASS CORRECTION OF RESTRAINT

VOLUME OF WEIGHTS BEING USED IN RESTRAINT AT 23.28

0.15925 MG

SYSTEMATIC ERROR IN THE RESTRAINT

3 STANDARD DEVIATION LIMIT FOR RANDOM ERROR AFFECTING RESTRAINT

$0.06024 \mathrm{CM}$

0.00087 MG

$0.00509 \mathrm{MG}$

$\begin{array}{lcccccccc}\text { CHECK STANDARD USED } & 12 & & & & & \\ \text { CHECK STANDARD VECTOR } & & 0 & 0 & 0 & 0 & 1 & 0 \\ \text { ACCEPTED MASS CORRECTION } & \text { OF } & \text { CHECK } & \text { STANDARD } & & -0.00854 \text { MG } \\ \text { REPORT VECTOR } & 1 & 1 & 1 & 1 & 1 & 0 & 0 & \end{array}$

TEST CONDITIONS

CORRECTED TEMPERATURE IN DEGREES C

CORRECTED PRESSURE IN MM HG

CORRECTED HUMIDITY IN PERCENT

COMPUTED AIR DENSITY IN MG/CM3

TEMPERATURE CORRECTION

PRESSURE CORRECTION

HUMIDITY CORRECTION

OBSERVED TEMPERATURE IN DEGREES C

OBSERVED PRESSURE IN MM HG

OBSERVED HUMIDITY IN PERCENT
BEFORE

$\begin{array}{ccc}\text { BEFORE } & \text { AFTER } & \text { AVERAGE } \\ 23.25 & 23.30 & 23.28 \\ 758.828 & 758.429 & 758.629 \\ 27.30 & 24.10 & 25.70 \\ 1.1863 & 1.1859 & 1.1861 \\ 0.00 & 0.00 & \\ -0.172 & -0.171 & \\ 0.00 & 0.00 & \\ 23.25 & 23.30 & \\ 759.000 & 758.600 & \\ 27.30 & 24.10 & \\ & & \end{array}$

$\begin{array}{ccccc}\text { WEIGHTS BEING } & \text { NOMINAL } & \text { DENSITY } & \text { COEFFICIENT } & \text { ACCEPTED } \\ \text { TESTED } & \text { VALUE G } & \text { G/CM3 AT 2OC } & \text { OF EXPANSION } & \text { CORRECTION MG }\end{array}$

$500 \mathrm{MG}$

30 OMG

$200 M G$

$100 \mathrm{MG}$

AN / 10OMG

SUM 10OMG
0.5000

0.3000

0.2000

0.1000

0.1000

0.1000
16. 6000

16.6000

16.6000

16.6000

8.4100

8.1788
.000020

.000020

.000020

.000020

.000039

.000049
$-0.00854$ 
COMPANY $X$

LOCUS, U.S.A.

SET OF MASS STANDARDS : 500 MG - $1 M G$

TEST NUMBER DEMO1

BALANCE 13

OPERATOR 39

CALIBRATION DESIGN 62

MG

\begin{tabular}{|c|c|c|c|c|c|c|c|}
\hline & & 500 & 300 & 200 & 100 & 100 & 100 \\
\hline A & 1 & + & - & - & + & - & \\
\hline A & 2 & + & - & - & & $t$ & - \\
\hline A & 3 & + & - & - & - & & + \\
\hline A & 4 & + & - & - & & & \\
\hline A & 5 & + & & - & - & - & - \\
\hline A & 6 & & + & - & + & - & - \\
\hline A & 7 & & + & - & - & + & - \\
\hline A & 8 & & + & - & - & - & + \\
\hline A & 9 & & & + & - & - & \\
\hline A & 10 & & & + & - & & - \\
\hline A & 11 & & & + & & - & - \\
\hline $\mathbf{R}$ & & + & + & + & & & \\
\hline
\end{tabular}

OBSERVATIONS IN DIVISIONS

DIRECT READING
A 1
20.4000
10020.4004
A 2
$-16.5000$
6.8500
4. 1000
A 4
$-28.8500$
A $6 \quad 8.8000$
A $7 \quad-26.7000$
A $8 \quad 14.2500$
A $9 \quad-25.3000$
A $10 \quad-45.2000$
A $11 \quad-28.3000$
9971.7002 
COMPANY $X$

LOCUS, U.S.A.

SET OF MASS STANDARDS : 500 MG - 1 MG

PAGE 12

TEST NUMBER DEMO 1

RIES 2

$8 / 29 / 86$

BALANCE 13

OPERATOR 39

CALIBRATION DESIGN 62

SENSITIVITY WEIGHT

\begin{tabular}{|c|c|c|}
\hline $10.00000 \mathrm{MC}$ & & \\
\hline 0.00000 & O СM3 АТ $20 \mathrm{C}$ & \\
\hline COEFFICIENT OF EXPANS & SION $\quad 0.000000$ & \\
\hline$S^{\star}=S-P V(S)=$ & $10.00000 \mathrm{MG}$ & \\
\hline CCEPTED SENSITIVIT & $=0.00100$ & $M G / D I V$ \\
\hline BSERVED SENSITIVITY & 0.00100 & MG / DIV \\
\hline
\end{tabular}

$\begin{array}{ll}\mathrm{T}-\mathrm{TEST} & =0.000\end{array}$

$\begin{array}{ccl} & & \text { OBSERVED } \\ \text { A (I) } & \text { DELTA(I) } & \text { SENSITIVITY } \\ \text { (MG) } & \text { (MG) } & \text { (MG/DIV) }\end{array}$

$\begin{array}{rrrr}\text { A } & 1 & 0.02040 & -0.00081 \\ \mathrm{~A} & 2 & -0.01650 & -0.00016 \\ \mathrm{~A} & 3 & 0.00685 & -0.00003 \\ \mathrm{~A} & 4 & 0.00410 & 0.00018 \\ \mathrm{~A} & 5 & -0.02885 & 0.00083 \\ \mathrm{~A} & 6 & 0.00880 & 0.00019 \\ \mathrm{~A} & 7 & -0.02670 & -0.00073 \\ \mathrm{~A} & 8 & 0.01425 & -0.00029 \\ \mathrm{~A} & 9 & -0.02530 & -0.00038 \\ \mathrm{~A} & 10 & -0.04520 & -0.00003 \\ \mathrm{~A} & 11 & -0.02830 & -0.00042\end{array}$

0.00100

$\begin{array}{ccc} & & \text { VOLUME } \\ \text { ITEM } & \text { CORRECTION } & \text { (AT T) } \\ \text { (G) } & \text { (MG) } & \text { (CM3) }\end{array}$

$\begin{array}{crc}\text { SYSTEMATIC } & \text { S.D. } & \text { UNCERTAINTY } \\ \text { ERROR } & \text { LIMIT } & \text { LIMIT } \\ \text { (MG) } & \text { (MG) } & \text { (MG) }\end{array}$

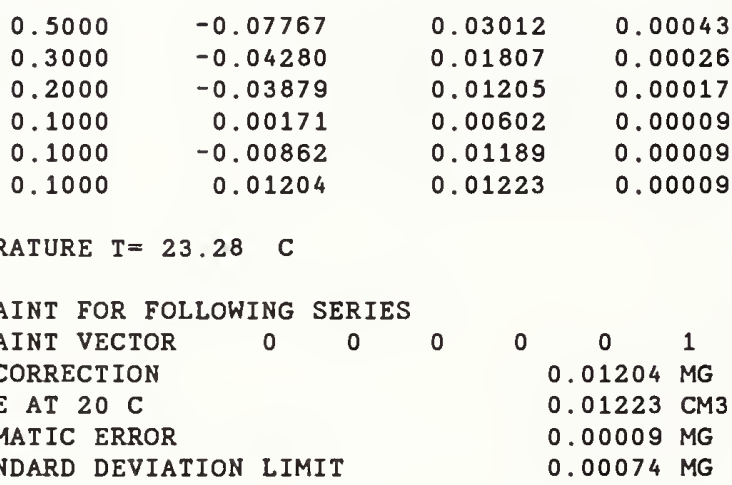


COMPANY $X$

LOCUS, U.S.A.

SET OF MASS STANDARDS : 500 MG - 1MG

PAGE 13

TEST NUMBER DEMO1

BALANCE 13

OPERATOR 39

CALIBRATION DESIGN 62

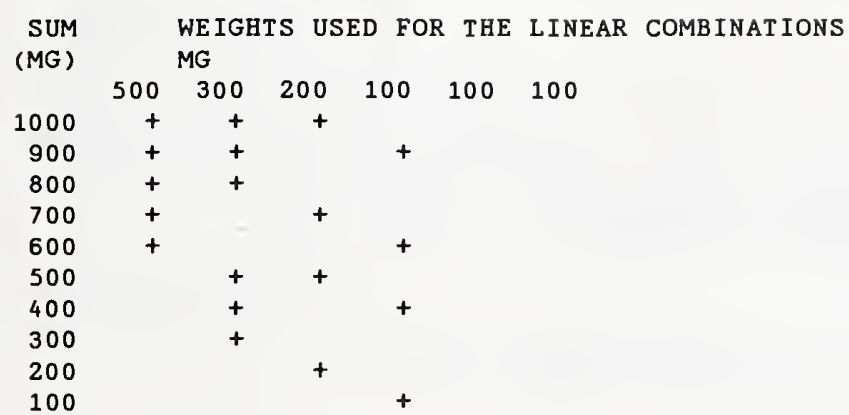

VALUES AND UNCERTAINTIES FOR COMBINATIONS OF WEIGHTS (UNCERTAINTY IS 3 STANDARD DEVIATION LIMIT PLUS ALLOWANCE FOR SYSTEMATIC ERROR.)

\begin{tabular}{|c|c|c|c|c|}
\hline $\begin{array}{l}\text { SUM } \\
\text { (MG) }\end{array}$ & $\begin{array}{l}\text { CORR } \\
\text { (MG) }\end{array}$ & $\begin{array}{l}\text { SYSTEMAT IC } \\
\text { (MG) }\end{array}$ & $\begin{array}{l}3 \text { S.D. } \\
\text { ERROR } \\
\text { (MG) }\end{array}$ & $\begin{array}{l}\text { UNCERTAIN } \\
\text { L IMIT } \\
\text { (MG) }\end{array}$ \\
\hline 1000 & -0.15925 & 0.00087 & 0.00509 & 0.00596 \\
\hline 900 & -0.11875 & 0.00078 & 0.00463 & 0.00542 \\
\hline 800 & -0.12046 & 0.00070 & 0.00409 & 0.00479 \\
\hline 700 & -0.11646 & 0.00061 & 0.00359 & 0.00420 \\
\hline 600 & -0.07595 & 0.00052 & 0.00312 & 0.00364 \\
\hline 500 & -0.08159 & 0.00043 & 0.00257 & 0.00300 \\
\hline 400 & -0.04108 & 0.00035 & 0.00216 & 0.00251 \\
\hline 300 & -0.04280 & 0.00026 & 0.00159 & 0.00185 \\
\hline 200 & -0.03879 & 0.00017 & 0.00109 & 0.00127 \\
\hline 100 & 0.00171 & 0.00009 & 0.00074 & 0.00082 \\
\hline
\end{tabular}


COMPANY $X$

LOCUS, U.S.A.

SET OF MASS STANDARDS : 500 MG - $1 M G$

PAGE 14

TEST NUMBER DEMO1

IES 2

$8 / 29 / 86$

BALANCE 13

OPERATOR 39

MAXIMUM LOAD

$0.6000 \mathrm{G}$

STARTING RESTRAINT NUMBER

CALIBRATION DESIGN 62

PRECISION CONTROL

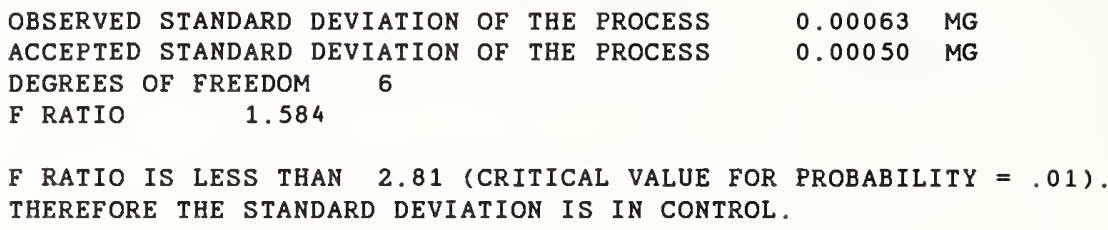

F RATIO IS LESS THAN 2.81 (CRITICAL VALUE FOR PROBABILITY $=.01$ ). THEREFORE THE STANDARD DEVIATION IS IN CONTROL.

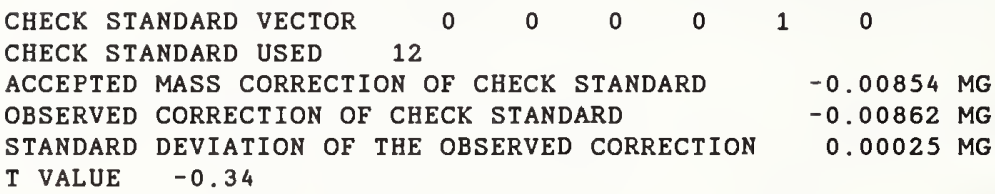

ABSOLUTE VALUE OF T IS LESS THAN 3.

THEREFORE CHECK STANDARD IS IN CONTROL.

TEST CONDITIONS

CORRECTED TEMPERATURE IN DEGREES C

CORRECTED PRESSURE IN MM HG

CORRECTED HUMIDITY IN PERCENT

COMPUTED AIR DENSITY IN MG/CM3

TEMPERATURE CORRECTION

PRESSURE CORRECTION

HUMIDITY CORRECTION

OBSERVED TEMPERATURE IN DEGREES C

OBSERVED PRESSURE IN MM HG

OBSERVED HUMIDITY IN PERCENT

$\begin{array}{cc}\text { BEFORE } & \text { AFTER } \\ 23.25 & 23.30 \\ 758.828 & 758.429 \\ 27.30 & 24.10 \\ 1.1863 & 1.1859 \\ 0.00 & 0.00 \\ -0.172 & -0.171 \\ 0.00 & 0.00 \\ 23.25 & 23.30 \\ 759.000 & 758.600 \\ 27.30 & 24.10\end{array}$

AVERAG

23.28

758.629

25.70

1. 1861 
COMPANY $X$

LOCUS, U.S.A.

SERIES 3

SET OF MASS STANDARDS : 500 MG - 1 MG

$8 / 30 / 86$

TEST NUMBER DEMO 1

BALANCE 13

OPERATOR 39

ACCEPTED WITHIN STANDARD DEVIATION OF THE PROCESS

ACCEPTED BETWEEN STANDARD DEVIATION OF THE PROCESS

$0.00050 \mathrm{MG}$

$0.00000 \mathrm{MG}$

CALIBRATION DESIGN 62

$\begin{array}{lllllll}\text { RESTRAINT VECTOR } & 1 & 1 & 1 & 0 & 0 & 0\end{array}$

MASS CORRECTION OF RESTRAINT

VOLUME OF WEIGHTS BEING USED IN RESTRAINT AT 23.00

SYSTEMATIC ERROR IN THE RESTRAINT

3 STANDARD DEVIATION LIMIT FOR RANDOM ERROR AFFECTING RESTRAINT

$0.01204 \mathrm{MG}$

$0.01223 \mathrm{CM} 3$

0.00009 MG

$0.00074 \mathrm{MG}$

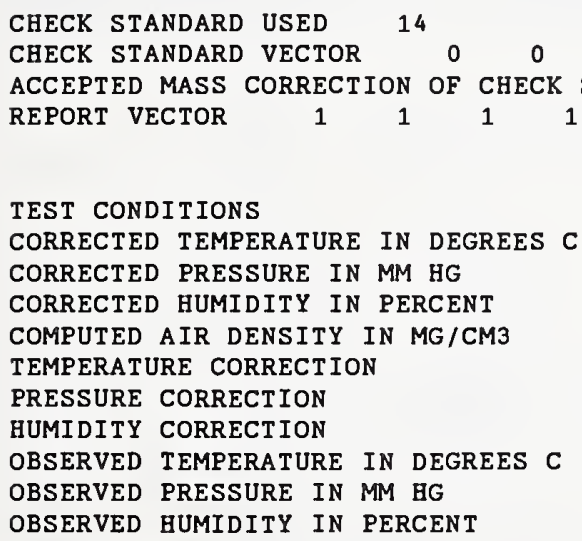

$\begin{array}{ccc}\text { BEFORE } & \text { AFTER } & \text { AVERAGE } \\ 22.95 & 23.05 & 23.00 \\ 760.227 & 760.027 & 760.127 \\ 30.00 & 30.70 & 30.35 \\ 1.1895 & 1.1886 & 1.1891 \\ 0.00 & 0.00 & \\ -0.173 & -0.173 & \\ 0.00 & 0.00 & \\ 22.95 & 23.05 & \\ 760.400 & 760.200 & \\ 30.00 & 30.70 & \\ & & \end{array}$

$\begin{array}{ccccc}\text { WEIGHTS BEING } & \begin{array}{c}\text { NOMINAL } \\ \text { TESTED }\end{array} & \begin{array}{c}\text { DENSITY } \\ \text { VALUE G }\end{array} & \begin{array}{c}\text { COEFFICIENT } \\ \text { G/CM3 AT 20C }\end{array} & \begin{array}{c}\text { ACCEPTED } \\ \text { OF EXPANSION }\end{array} \\ \text { CORRECTION MG }\end{array}$


COMPANY $X$

LOCUS, U.S.A.

SET OF MASS STANDARDS : 500 MG - 1MG

PAGE 16

SERIES 3

TEST NUMBER DEMO 1

BALANCE 13

OPERATOR 39

CALIBRATION DESIGN 62

MG

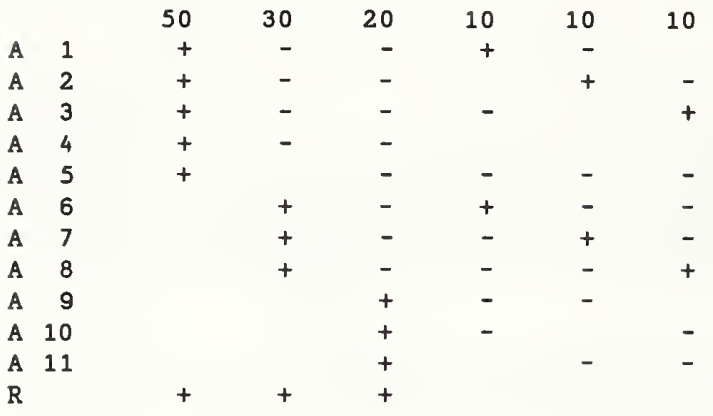

OBSERVATIONS IN DIVISIONS DIRECT READING

$\begin{array}{lrrr}\text { A } & 1 & 9.1000 & 10009.1006 \\ \text { A } & 2 & -43.2000 & \\ A & 3 & -0.1000 & \\ A & 4 & -11.4000 & \\ A & 5 & -59.6000 & \\ A & 6 & -13.8000 & \\ A & 7 & -55.7000 & \\ A & 8 & 8.4000 & \\ A & 9 & -11.8000 & \\ A & 10 & -43.8000 & \\ \text { A } & 11 & -24.0000 & 9976.0000\end{array}$


COMPANY $X$

LOCUS, U.S.A.

SET OF MASS STANDARDS : 500 MG - 1MG

TEST NUMBER DEMO 1

BALANCE 13

OPERATOR 39

CALIBRATION DESIGN 62

\section{SENSITIVITY WEIGHT}

MASS $\quad 10.00000 \mathrm{MG}$

VOLUME $\quad 0.00000$ CM3 AT $20 \mathrm{C}$

COEFFICIENT OF EXPANSION 0.000000

$$
S *=S-P V(S)=
$$
10.00000 MG

ACCEPTED SENSITIVITY $=0.00100 \mathrm{MG} / \mathrm{DIV}$

OBSERVED SENSITIVITY $=0.00100 \mathrm{MG} / \mathrm{DIV}$

T-TEST $=0.000$

$\begin{array}{ccc} & & \\ \text { A(I) } & \text { OBSERVED } \\ \text { (MG) } & \text { DELTA(I) } & \text { SENSITIVITY } \\ & \text { (MG) } & \text { (MG/DIV) }\end{array}$

$\begin{array}{rrrrr}\text { A } & 1 & 0.00910 & 0.00003 & 0.00100 \\ \text { A } & 2 & -0.04320 & 0.00032 & \\ \text { A } & 3 & -0.00010 & 0.00016 & \\ \text { A } & 4 & -0.01140 & 0.00017 & \\ \text { A } & 5 & -0.05960 & -0.00068 & \\ \text { A } & 6 & -0.01380 & 0.00058 & \\ \text { A } & 7 & -0.05570 & -0.00005 & \\ \text { A } & 8 & 0.00840 & 0.00015 & \\ \text { A } & 9 & -0.01180 & 0.00054 & \\ \text { A } & 10 & -0.04380 & 0.00049 & \\ \text { A } & 11 & -0.02400 & -0.00035 & 0.00100\end{array}$

$\begin{array}{cccccc} & & \text { VOLUME } & \text { SYSTEMATIC } & \text { 3 S.D. } & \text { UNCERTAINTY } \\ \text { ITEM } & \text { CORRECTION } & \text { (AT T) } & \text { ERROR } & \text { LIMIT } & \text { LIMIT } \\ \text { (G) } & \text { (MG) } & (\text { CM3) } & (M G) & \text { (MG) } & \text { (MG) }\end{array}$

$\begin{array}{lrllll}0.0500 & -0.00346 & 0.00301 & 0.00004 & 0.00051 & 0.00055 \\ 0.0300 & 0.00198 & 0.00181 & 0.00003 & 0.00050 & 0.00053 \\ 0.0200 & 0.01351 & 0.00741 & 0.00002 & 0.00042 & 0.00044 \\ 0.0100 & 0.02325 & 0.00371 & 0.00001 & 0.00054 & 0.00055 \\ 0.0100 & -0.00039 & 0.00119 & 0.00001 & 0.00054 & 0.00055 \\ 0.0100 & 0.03457 & 0.00372 & 0.00001 & 0.00054 & 0.00055\end{array}$

TEMPERATURE $\mathrm{T}=23.00 \mathrm{C}$

RESTRAINT FOR FOLLOWING SERIES

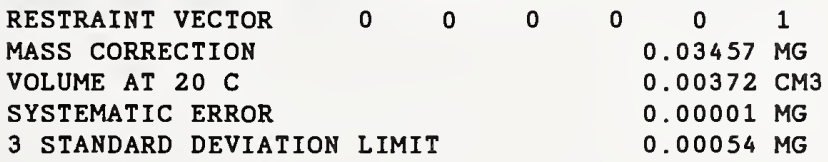


COMPANY X

LOCUS, U.S.A.

SET OF MASS STANDARDS : 500 MG - $1 M G$

PAGE 18

SERIES 3

TEST NUMBER DEMO 1

BALANCE 13

OPERATOR 39

CALIBRATION DESIGN 62

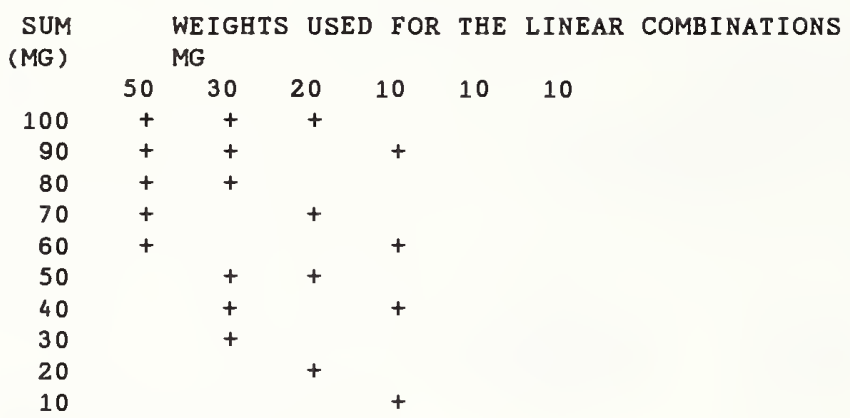

VALUES AND UNCERTAINTIES FOR COMBINATIONS OF WEIGHTS (UNCERTAINTY IS 3 STANDARD DEVIATION LIMIT PLUS ALLOWANCE FOR SYSTEMATIC ERROR.)

\begin{tabular}{|c|c|c|c|c|}
\hline $\begin{array}{l}\text { SUM } \\
\text { (MG) }\end{array}$ & $\begin{array}{l}\text { CORR } \\
\text { (MG) }\end{array}$ & $\begin{array}{c}\text { SYSTEMATIC } \\
\text { (MG) }\end{array}$ & $\begin{array}{l}3 \text { S.D. } \\
\text { ERROR } \\
\text { (MG) }\end{array}$ & $\begin{array}{l}\text { UNCERTAINTY } \\
\text { LIMIT } \\
\text { (MG) }\end{array}$ \\
\hline 100 & 0.01204 & 0.00009 & 0.00074 & 0.00082 \\
\hline 90 & 0.02178 & 0.00008 & 0.00096 & 0.00104 \\
\hline 80 & -0.00147 & 0.00007 & 0.00071 & 0.00078 \\
\hline 70 & 0.01006 & 0.00006 & 0.00068 & 0.00074 \\
\hline 60 & 0.01980 & 0.00005 & 0.00078 & 0.00083 \\
\hline 50 & 0.01550 & 0.00004 & 0.00051 & 0.00055 \\
\hline 40 & 0.02523 & 0.00003 & 0.00077 & 0.00081 \\
\hline 30 & 0.00198 & 0.00003 & 0.00050 & 0.00053 \\
\hline 20 & 0.01351 & 0.00002 & 0.00042 & 0.00044 \\
\hline 10 & 0.02325 & 0.00001 & 0.00054 & 0.00055 \\
\hline
\end{tabular}


COMPANY $\mathrm{X}$

PAGE 20

LOCUS, U.S.A.

SET OF MASS STANDARDS : 500 MG - 1 MG

SERIES 4

TEST NUMBER DEMO 1

$8 / 30 / 86$

BALANCE 13

OPERATOR 39

ACCEPTED WITHIN STANDARD DEVIATION OF THE PROCESS

$0.00050 \mathrm{MG}$

ACCEPTED BETWEEN STANDARD DEVIATION OF THE PROCESS

$0.00000 \mathrm{MG}$

CALIBRATION DESIGN 62

$\begin{array}{lllllll}\text { RESTRAINT VECTOR } & 1 & 1 & 1 & 0 & 0 & 0\end{array}$

MASS CORRECTION OF RESTRAINT

VOLUME OF WEIGHTS BEING USED IN RESTRAINT AT 22.95

$0.03457 \mathrm{MG}$

SYSTEMATIC ERROR IN THE RESTRAINT

$0.00372 \mathrm{CM}$

3 STANDARD DEVIATION LIMIT FOR RANDOM ERROR AFFECTING RESTRAINT

$0.00001 \mathrm{MG}$

$0.00054 \mathrm{MG}$

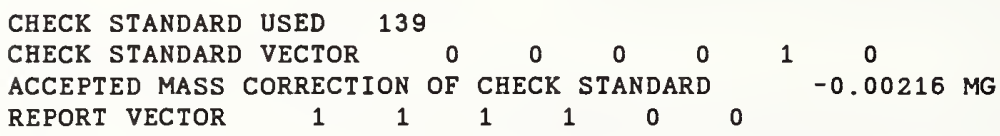

TEST CONDITIONS

CORRECTED TEMPERATURE IN DEGREES C

BEFORE
22.90
759.527
31.60
1.1884
0.00
-0.173
0.00
22.90
759.700
31.60

AFTER
23.00
759.327
32.60
1.1875
0.00
-0.173
0.00
23.00
759.500
32.60

AVERAGE

22.95

CORRECTED PRESSURE IN MM HG

CORRECTED HUMIDITY IN PERCENT

COMPUTED AIR DENSITY IN MG/CM3

TEMPERATURE CORRECTION

PRESSURE CORRECTION

HUMIDITY CORRECTION

OBSERVED TEMPERATURE IN DEGREES C

OBSERVED PRESSURE IN MM HG

OBSERVED HUMIDITY IN PERCENT

759.427

32.10

1.1879

WEIGHTS BEING
TESTED

5MG

3MG

2MG

IMG

T 1MG

SUM 1 MG

NOMINAL
VALUE G
0.0050
0.0030
0.0020
0.0010
0.0010
0.0010

DENSITY

G/CM3 AT 20C

COEFFICIENT

OF EXPANSION

ACCEPTED

2.7000

2.7000

2.7000

2.7000

8.5000

2.7000
.000069

.000069

.000069

.000069

.000039

.000069
$-0.00216$ 
COMPANY $X$

LOCUS, U.S.A.

SET OF MASS STANDARDS : 500 MG - IMG

PAGE 21

TEST NUMBER DEMO1

BALANCE 13

OPERATOR 39

CALIBRATION DESIGN 62

MG

$\begin{array}{llllllll} & & 5 & 3 & 2 & 1 & 1 & 1 \\ \text { A } & 1 & + & - & - & + & - & \\ \text { A } & 2 & + & - & - & & + & - \\ \text { A } & 3 & + & - & - & - & & + \\ \text { A } & 4 & + & - & - & & & \\ \text { A } & 5 & + & & - & - & - & - \\ \text { A } & 6 & & + & - & + & - & - \\ \text { A } & 7 & & + & - & - & + & - \\ \text { A } & 8 & & + & - & - & - & + \\ \text { A } & 9 & & & + & - & - & - \\ \text { A } & 10 & & & + & - & & - \\ \text { A } & 11 & & & + & & - & - \\ \text { R } & & + & + & + & & & \end{array}$

OBSERVATIONS IN DIVISIONS

DIRECT READING
A 1
8.4000
10008.4004
A 22.4000
A $3 \quad-8.8000$
A $4 \quad 1.1000$
A $5 \quad 7.2000$
A $6 \quad 6.0000$
A $7 \quad-9.1000$
A $8 \quad-11.2000$
A $9 \quad 7.6000$
A $10 \quad 8.0000$
A 11
17.8000
10017.7998 
COMPANY $\mathrm{X}$

LOCUS, U.S.A.

SET OF MASS STANDARDS : 500 MG - 1MG

PAGE 22

SERIES 4

TEST NUMBER DEMO1

BALANCE 13

OPERATOR 39

CALIBRATION DESIGN 62

SENSITIVITY WEIGHT

MASS $\quad 10.00000 \mathrm{MG}$

VOLUME 0.00000 CM3 AT $20 \mathrm{C}$

COEFFICIENT OF EXPANSION 0.000000

$$
S^{*}=S-P V(S)=\quad 10.00000 \mathrm{MG}
$$

ACCEPTED SENSITIVITY $=0.00100 \mathrm{MG} / \mathrm{DIV}$

OBSERVED SENSITIVITY $=0.00100 \mathrm{MG} / \mathrm{DIV}$

$\begin{array}{ll}\mathrm{T}-\mathrm{TEST} & =0.000\end{array}$

$\begin{array}{ccc} & & \text { OBSERVED } \\ \text { A (I) } & \text { DELTA(I) } & \text { SENSITIVITY } \\ \text { (MG) } & \text { (MG) } & \text { (MG/DIV) }\end{array}$

$\begin{array}{rrrrr}\mathrm{A} & 1 & 0.00840 & -0.00028 & 0.00100 \\ \mathrm{~A} & 2 & 0.00240 & 0.00039 & \\ \mathrm{~A} & 3 & -0.00880 & -0.00046 & \\ \mathrm{~A} & 4 & 0.00110 & 0.00032 & \\ \mathrm{~A} & 5 & 0.00720 & 0.00003 & \\ \mathrm{~A} & 6 & 0.00600 & -0.00059 & \\ \mathrm{~A} & 7 & -0.00910 & 0.00011 & \\ \mathrm{~A} & 8 & -0.01120 & 0.00046 & \\ \mathrm{~A} & 9 & 0.00760 & -0.00009 & \\ \mathrm{~A} & 10 & 0.00800 & -0.00092 & \\ \mathrm{~A} & 11 & 0.01780 & 0.00098 & 0.00100\end{array}$

$\begin{array}{cccccc} & & \text { VOLUME } & \text { SYSTEMATIC } & \text { 3 S.D. } & \text { UNCERTAINTY } \\ \text { ITEM } & \text { CORRECTION } & (\text { AT T) } & \text { ERROR } & \text { LIMIT } & \text { LIMIT } \\ (G) & (M G) & (C M 3) & (M G) & (M G) & (M G)\end{array}$

$\begin{array}{lrllll}0.0050 & 0.01768 & 0.00186 & 0.00000 & 0.00044 & 0.00045 \\ 0.0030 & 0.00600 & 0.00111 & 0.00000 & 0.00048 & 0.00048 \\ 0.0020 & 0.01089 & 0.00074 & 0.00000 & 0.00041 & 0.00041 \\ 0.0010 & 0.00555 & 0.00037 & 0.00000 & 0.00054 & 0.00054 \\ 0.0010 & -0.00265 & 0.00012 & 0.00000 & 0.00054 & 0.00054 \\ 0.0010 & -0.00358 & 0.00037 & 0.00000 & 0.00054 & 0.00054\end{array}$

TEMPERATURE $T=22.95 \mathrm{C}$ 
COMPANY $\mathrm{X}$

LOCUS, U.S.A.

SET OF MASS STANDARDS : 500 MG - 1MG

PAGE 23

TEST NUMBER DEMO1

BALANCE 13

OPERATOR 39

CALIBRATION DESIGN 62

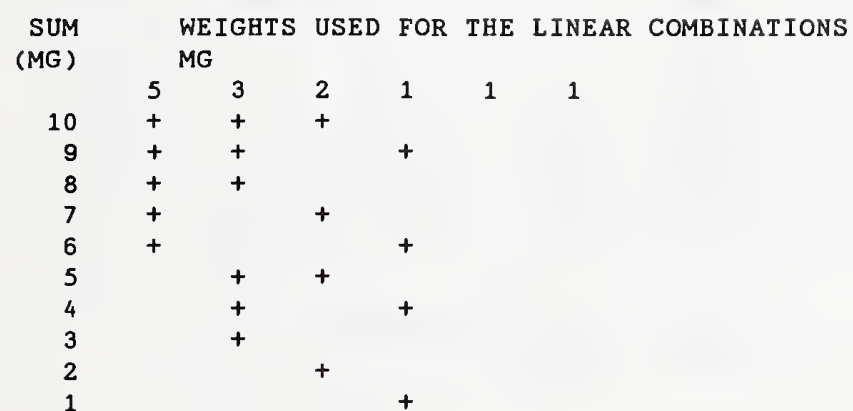

VALUES AND UNCERTAINTIES FOR COMBINATIONS OF WEIGHTS (UNCERTAINTY IS 3 STANDARD DEVIATION LIMIT PLUS ALLOWANCE FOR SYSTEMATIC ERROR.)

\begin{tabular}{|c|c|c|c|c|}
\hline $\begin{array}{l}\text { SUM } \\
\text { (MG) }\end{array}$ & $\begin{array}{l}\text { CORR } \\
\text { (MG) }\end{array}$ & $\begin{array}{l}\text { SYSTEMAT IC } \\
\text { (MG) }\end{array}$ & $\begin{array}{l}3 \text { S.D. } \\
\text { ERROR } \\
\text { (MG) }\end{array}$ & $\begin{array}{l}\text { UNCERTAIN } \\
\text { L IMI T } \\
\text { (MG) }\end{array}$ \\
\hline 10 & 0.03457 & 0.00001 & 0.00054 & 0.00055 \\
\hline 9 & 0.02923 & 0.00001 & 0.00084 & 0.00085 \\
\hline 8 & 0.02368 & 0.00001 & 0.00058 & 0.00059 \\
\hline 7 & 0.02857 & 0.00001 & 0.00058 & 0.00059 \\
\hline 6 & 0.02322 & 0.00001 & 0.00072 & 0.00073 \\
\hline 5 & 0.01689 & 0.00000 & 0.00044 & 0.00045 \\
\hline 4 & 0.01155 & 0.00000 & 0.00075 & 0.00075 \\
\hline 3 & 0.00600 & 0.00000 & 0.00048 & 0.00048 \\
\hline 2 & 0.01089 & 0.00000 & 0.00041 & 0.00041 \\
\hline 1 & 0.00555 & 0.00000 & 0.00054 & 0.00054 \\
\hline
\end{tabular}


COMPANY $X$

LOCUS, U.S.A.

SET OF MASS STANDARDS : 500 MG - 1MG

PAGE 24

SERIES 4

TEST NUMBER DEMO1

$8 / 30 / 86$

BALANCE 13

OPERATOR 39

MAXIMUM LOAD

STARTING RESTRA INT

CALIBRATION DESIGN 62

PRECISION CONTROL

OBSERVED STANDARD DEVIATION OF THE PROCESS

ACCEPTED STANDARD DEVIATION OF THE PROCESS

$0.00070 \quad M G$ DEGREES OF FREEDOM 6

F RATIO 1.955

F RATIO IS LESS THAN 2.81 (CRITICAL VALUE FOR PROBABILITY $=.01$ ). THEREFORE THE STANDARD DEVIATION IS IN CONTROL.

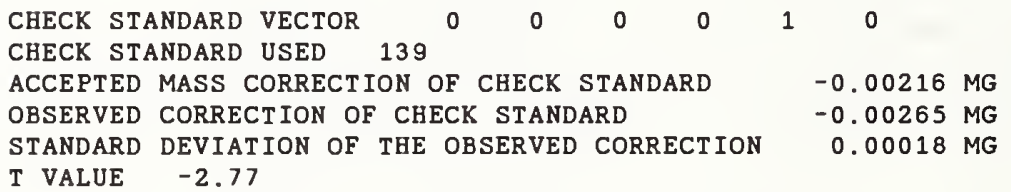

ABSOLUTE VALUE OF T IS LESS THAN 3 .

THEREFORE CHECK STANDARD IS IN CONTROL.

TEST CONDITIONS

CORRECTED TEMPERATURE IN DEGREES C CORRECTED PRESSURE IN MM HG CORRECTED HUMIDITY IN PERCENT COMPUTED AIR DENSITY IN MG/CM3 TEMPERATURE CORRECTION

PRESSURE CORRECTION

HUMIDITY CORRECTION

OBSERVED TEMPERATURE IN DEGREES C

OBSERVED PRESSURE IN MM HG

OBSERVED HUMIDITY IN PERCENT

$\begin{array}{ccc}\text { BEFORE } & \text { AFTER } & \text { AVERAGE } \\ 22.90 & 23.00 & 22.95 \\ 759.527 & 759.327 & 759.427 \\ 31.60 & 32.60 & 32.10 \\ 1.1884 & 1.1875 & 1.1879 \\ 0.00 & 0.00 & \\ -0.173 & -0.173 & \\ 0.00 & 0.00 & \\ 22.90 & 23.00 & \\ 759.700 & 759.500 & \\ 31.60 & 32.60 & \\ & & \end{array}$




\section{SUMMARY}

FOR CONVENIENCE, THE RESULTS OF THIS WORK ARE SUMMARIZED IN TABLES I AND II. THE VALUES ASSIGNED ARE WITH REFERENCE TO THE STANDARDS IDENTIFIED ON THE DATA SHEETS. THE UNCERTAINTY FIGURE IS AN EXPRESSION OF THE OVERALL UNCERTAINTY USING THREE STANDARD DEVIATIONS AS A LIMIT TO THE EFFECT OF RANDOM ERRORS OF THE MEASUREMENT ASSOCIATED WITH THE MEASUREMENT PROCESSES. THE MAGNITUDE OF SYSTEMATIC ERRORS FROM SOURCES OTHER THAN THE USE OF ACCEPTED VALUES FOR CERTAIN STARTING STANDARDS ARE CONSIDERED NEGLIGIBLE. IT SHOULD BE NOTED THAT THE MAGNITUDE OF THE UNCERTAINTY REFLECTS THE PERFORMANCE OF THE MEASUREMENT PROCESS USED TO ESTABLISH THESE VALUES. THE MASS UNIT, AS REALIZABLE IN ANOTHER MEASUREMENT PROCESS, WILL BE UNCERTAIN BY AN AMOUNT WHICH IS A COMBINATION OF THE UNCERTAINTY OF THIS PROCESS AND THE PROCESS IN WHICH THESE STANDARDS ARE USED.

THE ESTIMATED MASS VALUES LISTED IN TABLE I ARE BASED ON AN EXPLICIT TREATMENT OF DISPLACEMENT VOLUMES, E.G., 'TRUE MASS', 'MASS IN VACUO', MASS IN THE NEWTONIAN SENSE. THE DISPLACEMENT VOLUME ASSOCIATED WITH EACH VALUE IS LISTED AS WELL AS THE VOLUMETRIC COEFFICIENT OF EXPANSION. THESE VALUES SHOULD BE USED, TOGETHER WITH APPROPRIATE CORRECTION FOR THE BUOYANT EFFECTS OF THE ENVIRONMENT, TO ESTABLISH CONSISTENT MASS VALUES FOR OBJECTS WHICH DIFFER SIGNIFICANTLY IN DENSITY AND/OR FOR MEASUREMENTS WHICH MUST BE MADE IN DIFFERING ENVIRONMENTS. THE RELATION 1LB AVDP $=.45359237 \mathrm{KG}$ IS USED AS REQUIRED.
THE ESTIMATED MASS VALUES LISTED IN TABLE II ARE BASED ON AN IMPLICIT TREATMENT OF DISPLACEMENT VOLUMES, E.G., 'APPARENT MASS', 'APPARENT MASS VERSUS BRASS', 'APPARENT MASS VERSUS DENSITY 8. $0^{\circ}$. THE VALUES ARE LISTED AS CORRECTIONS TO BE APPLIED TO THE LISTED NOMINAL VALUE (A POSITIVE CORRECTION INDICATES THAT THE MASS IS LARGER THAN THE STATED NOMINAL VALUE BY THE AMOUNT OF THE CORRECTION). THESE VALUES ARE COMPUTED FROM THE VALUES BASED ON AN EXPLICIT TREATMENT OF DISPLACEMENT VOLUMES USING THE FOLLOWING DEFINING RELATIONS AND ARE UNCERTAIN BY THE AMOUNT SHOWN IN TABLE I.

THE ADJUSTMENT OF WEIGHTS TO MINIMIZE THE DEVIATION FROM NOMINAL ON THE BASIS OF 'NORMAL BRASS' (IN ACCORDANCE WITH COR. A BELOW) IS WIDESPREAD IN THIS COUNTRY AND IN MANY PARTS OF THE WORLD. VALUES STATED ON EITHER BASIS ARE INTERNALLY CONSISTENT AND DEFINITE. THERE IS, HOWEVER, A SYSTEMATIC DIFFERENCE BETWEEN THE VALUES ASSIGNED ON EACH BASIS, THE VALUE ON THE BASIS OF 'DENSITY 8.0' BEING 7 MICROGRAMS/GRAM LARGER THAN THE VALUE ON THE BASIS OF NORMAL BRASS. THIS SYSTEMATIC DIFFERENCE IS CLEARLY DETECTABLE ON MANY DIRECT READING BALANCES.

CORRECTION A - 'APPARENT MASS VERSUS BRASS' OR 'WEIGHT IN AIR AGAINST BRASS' IS DETERMINED BY A HYPOTHETICAL WEIGHING OF THE WEIGHT AT 20 CELSIUS IN AIR HAVING A DENSITY OF 1.2 MG/CM3, WITH A (NORMAL BRASS) STANDARD HAVING A DENSITY OF 8.4 G/CM3 AT 0 CELSIUS WHOSE COEFFICIENT OF VOLUMETRIC EXPANSION IS $0.000 \quad 054$ PER DEGREE CELSIUS, AND WHOSE VALUE IS BASED 
COMPANY $X$

PAGE 26

LOCUS, U.S.A.

$8 / 30 / 86$

SET OF MASS STANDARDS : 500 MG - 1MG

TEST NUMBER $S$

ON ITS TRUE MASS OR WEIGHT IN VACUO.

CORRECTION B - 'APPARENT MASS VERSUS DENSITY $8.0^{\circ}$ IS DETERMINED

BY A HYPOTHETICAL WEIGHING OF THE

WEIGHT, IN AIR BAVING A DENSITY OF 1.2 MG/CM3, WITH A STANDARD HAVING A DENSITY OF 8.0 G/CM3 AT 20 CELSIUS, AND WHOSE VALUE IS BASED ON ITS TRUE MASS OR WEIGHT IN VACUO. 
COMPANY $X$

LOCUS, U.S.A.

SET OF MASS STANDARDS : 500 MG - $1 M G$

TEST NUMBER DEMO 1

TABLE I

I I EM

$500 M G$

$300 M G$

$200 M G$

$100 M G$

NEW SOMG

उOMG

$2 O M G$

$10 M G$

5MG

3MG

2MG

1MG
MASS

(G)

.49992233

.29995722

.19996121

.10000171

.04999654

.03000198

.02001351

.01002325

.00501768

.00300600

.00201089

.00100555
UNCERTAINTY

(G)

0.00000300

0.00000185

0.00000127

0.00000082

0.00000055

0.00000053

0.00000044

0.00000055

0.00000045

0.00000048

0.00000041

0.00000054
VOL AT 20 COEF OF EXP

(CM3)

0.030120 .000020

$0.01807 \quad 0.000020$

0.012050 .000020

$0.00602 \quad 0.000020$

0.003010 .000020

0.001810 .000020

0.007410 .000069

0.003710 .000069

0.001860 .000069

0.001110 .000069

0.000740 .000069

0.000370 .000069 
COMPANY $X$

PAGE 28

LOCUS, U.S.A.

$8 / 30 / 86$

SET OF MASS STANDARDS : 500 MG - 1 MG TEST NUMBER DEMO1

TABLE II

ITEM

$500 M G$

$300 M G$

$200 \mathrm{MG}$

$100 \mathrm{MG}$

NEW $50 \mathrm{MG}$

$30 M G$

$20 M G$

$10 M G$

5MG

3MG

2MG

IMG
COR.A (MG)

$-.04231$

$-.02158$

$-.02465$

.00879

.00008

.00410

.00748

.02023

.01616

.00510

.01028

.00525
COR.B (MG)

$-.03881$

$-.01948$

$-.02325$

.00948

.00043

.00431

.00762

.02030

.01620

.00512

.01030

.00525 


\section{Appendix C}

Surveillance Test

The following is the report of a surveillance test [7]. Subsequent to a calibration such as that shown in Appendix B, weights may be resubmitted for periodic surveillance. Surveillance is a more rapid and less costly procedure than calibration. The surveillance test can provide assurance that the values of mass previously assigned to a set of weights are still valid. 
September 18,1986

In reply refer to:

Subject:

Items:

The above items have been intercompared in sums. The differences as measured have been compared with the differences computed from the values under 225716-B. One or more of the items have been checked against national standards. The results of this test indicate that there is no significant change since the last calibration. This test assures the continuing accuracy of the values under 225716-B.

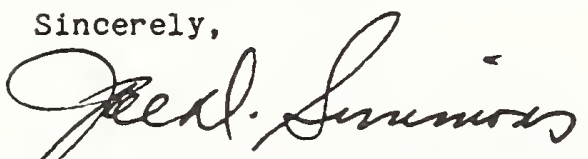

LOE D. SIMMONS, Deputy Director

Center for Basic Standards

At.tachment 


\section{Appendix D}

Calibration of Dead Weights

The following is a typical report of calibration for a set of dead weights. 


\section{REPORT OF CALIBRATION}

NBS Test Number:

For:

Items:

The above items have the mass values shown with reference to the NBS standard of mass.

$\begin{array}{lccr}\text { Item } & \begin{array}{c}\text { Mass } \\ (\mathrm{g})\end{array} & \begin{array}{c}\text { Uncertainty } \\ (\mathrm{g})\end{array} & \begin{array}{r}\text { Density } \\ (\mathrm{g} / \mathrm{cm} 3)\end{array} \\ 1 \mathrm{~kg}-1 & 999.9968 & 0.0033 & 7.92 \\ 1 \mathrm{~kg}-2 & 999.9985 & 0.0033 & 7.92 \\ 1 \mathrm{~kg}-3 & 1000.0007 & 0.0033 & 7.92 \\ 1 \mathrm{~kg}-4 & 999.9969 & 0.0033 & 7.92 \\ 1 \mathrm{~kg}-5 & 999.9960 & 0.0033 & 7.92 \\ 1 \mathrm{~kg}-6 & 999.9952 & 0.0033 & 7.92\end{array}$

The uncertainty figure is an expression of the overall uncertainty using three standard deviation as a limit to the effect of random errors of measurement plus the systematic errors, assuming the density is correct within 1\%. Test conditions: mass computed using air density $1.175 \mathrm{mg} / \mathrm{cm}^{3}$ for all items. 
The National Bureau of Standards uses the following relationship between the metric unit of mass and the U.S. customary unit of mass: one pound (avoirdupois) equals $0.45359237 \mathrm{kilogram}$.

For the Director,

National Measurement Laboratory

Joe D. Simmons, Chies

Length and Mass Division

Center for Basic Standards

'usi completed: September 3, 1986

Note: Mass and associated density values listed above are appropriate for $M_{m}$ and $p_{m}$ in Equation (24) from NBS Monograph 65 , "Reduction of Data for Piston Gage Pressure Measurements." 

4. TITLE AND SUBTITLE

NIST Measurement Services: Mass Calibrations

\section{AUTHOR(S)}

Richard S. Davis

6. PERFORMING ORGANIZATION (If joint or other than NBS, see instructions)

7. Contract/Grant No.

NATIONAL INSTITUTE OF STANDARDS AND TECHNOLOGY

(formerly NATIONAL BUREAU OF STANDARDS)

U.S. DEPARTMENT OF COMMERCE

GATTHERSBURG, MD 20899

8. Type of Report \& Period Covered Final

9. SPONSORING ORGANIZATION NAME AND COMPLETE ADDRESS (Street, City, State, ZIP)

Same as Item \#6

\section{SUPPLEMENTARY NOTES}

Library of Congress Catalog Card Number: 88-600608

[Document describes a computer program; SF-18S, FIPS Software Summary, is attached.

11. ABSTRACT (A 200-word or less factual summary of most significant information. If document includes a significant bibliography or literature survey, mention it here)

The NIST calibration service for standard masses is described. Weights which are accepted for calibration range in nominal values from $1 \mathrm{mg}$ to $13,600 \mathrm{~kg}$ $(30,000$ pounds $)$. We also accept weights used to generate standard pressures in piston gages. Cleaning procedures used on weights prior to calibration are described. The measurement algorithms (including density determinations of single-piece kilogram weights) and the uncertainties assigned to calibrated weights are discussed. We also describe the system now in place to monitor the quality of calibrations. Finally, we assess the limitations of the present controls on measurement quality and outline improvements which are underway.

12. KEY WORDS (Six to twelve entries; alphabetical order; capitalize only proper names; and separate key words by semicolons) calibration; density; kilogram; least squares; mass; piston weights; uncertainty

\section{AVAILABILITY}

X Unlimited

$\square$ For Official Distribution. Do Not Release to NTIS

[X] Order From Superintendent of Documents, U.S. Government Printing Office, Washington, D.C. 20402.

X] Order From National Technical Information Service (NTIS), Springfield, VA. 2216I
14. NO. OF PRINTED PAGES

72

15. Price 

SP 250-1 Spectral Radiance Calibrations SN003-003-02792-8 \$3.50

SP 250-2 Far Ultraviolet Detector Standards PB87227609

SP 250-3 Radiometric Standards in the Vacuum Ultraviolet SN003-003-02806-1 \$6.50

SP 250-4 Fricke Dosimetry in High-Energy Electron Beams SN003-003-02816-9 \$2.75

SP 250-5 Alpha-Particle Calibrations SN003-003-02823-1 \$2.00

SP 250-6 Regular Spectral Transmittance SN003-003-02805-3 \$3.25

SP 250-7 Radiance Temperature Calibrations SN003-003-02827-4 \$2.25

SP 250-8 Spectral Reflectance PB88109905

SP 250-9 Calibration of Beta-Particle-Emitting Ophthalmic Applicators SN003-003-02817-7 \$2.00

SP 250-10 Radioactivity Calibrations with the " $4 \pi$ " Gamma lonization Chamber, and Other Radioactivity Calibration Capabilities SN003-003-02824-0 \$2.25

SP 250-11 Dosimetry for High-Dose Applications SN003-003-02854-1 \$2.75

SP 250-12 Neutron Personnel Dosimetry SN003-003-02811-8 \$2.50

SP 250-13 Activation Foil Irradiation with Californium Fission Sources SN003-003-02866-5 \$2.25

SP 250-14 Activation Foil Iradiation by Reactor Cavity Fission Sources

SN003-003-02861-4 \$3.25

SP 250-15 Photometric Calibrations PB88153747

SP 250-16 Calibration of X-Ray and Gamma-Ray Measuring Instruments SN003-003-02862-2 \$7.00

SP 250-17 The NBS Photodetector Spectral Response Calibration Transfer Program SN003-003-02857-6 \$3.25
SP 250-18 Neutron Source Strength Calibrations SN003-003-02863-1 \$3.25

SP 250-19 Calibration of Gamma-Ray-Emitting Brachytherapy Sources

SP 250-20 Spectral Irradiance Calibrations SN003-003-02829-1 \$5.50

SP 250-21 Calibration of Beta-Particle Radiation Instrumentation PB88201579

SP 250-22 Platinum Resistance Thermometer Calibrations PB88138367

SP 250-23 Liquid-in-Glass Thermometer Calibration Service SN003-003-02891-6

SP 250-24 Standard Cell Calibrations SN003-003-02825-8 \$2.75

SP 250-25 Calibration Service for Inductive Voltage Dividers

SP 250-26 Phase Angle Calibrations SN003-003-02871-1 \$5.00

SP 250-27 AC-DC Difference Calibrations

SP 250-28 Solid-State DC Voltage Standard Calibrations SN003-003-02842-8 \$2.00

SP 250-29 Traceable Frequency Calibrations SN003-003-02844-4 \$2.25

SP 250-30 GOES Satellite Time Code Dissemination: Description and Operation SN003-003-02845-2 \$2.75

SP 250-31 Mass Calibrations

SP 250-32 A Calibration Service for $30 \mathrm{MHz}$ Attenuation and Phase Shift SN003-003-02875-4

SP 250-33 A Calibration Service for Voltage Transformers and High-Voltage Capacitors SN003-003-02880-1 \$1.25

SP 250-34 High Vacuum Standard and Its Use

\footnotetext{
* Those entries containing a stock number (003-003---) and price can be purchased from the Superintendent of Documents, U.S. Government Printing Office, Washington, DC 20402. GPO will accept checks, money orders, VISA, and Mastercharge. For more infomation, or to place an order, call (202) 783-3238. Be sure to use the stock number in all orders.

Entries containing PB numbers can be purchased from the National Technical Information Service, Springfield, VA 22161. NTIS will accept American Express in addition to the payment methods listed for GPO. For more information call (703) 487-4650; to place an order call (800) 336-4700. Be sure to use the PB number on all orders.

Titles without stock numbers are in preparation.
} 
U.S. Department of Commerce

National Institute of Standards and Technology

(formerly National Bureau of Standards)

Gaithersburg, MD 20899

Official Business

Penalty for Private Use $\$ 300$ 